\title{
The Neurotrophic Effects of Glial Cell Line-Derived Neurotrophic Factor on Spinal Motoneurons Are Restricted to Fusimotor Subtypes
}

\author{
Thomas W. Gould, ${ }^{1}$ Shigenobu Yonemura, ${ }^{2}$ Ronald W. Oppenheim, ${ }^{3}$ Shiho Ohmori, ${ }^{1}$ and Hideki Enomoto ${ }^{1}$ \\ ${ }^{1}$ Laboratory for Neuronal Differentiation and Regeneration and ${ }^{2}$ Laboratory for Cellular Morphogenesis, RIKEN Center for Developmental Biology, Kobe \\ 650-0047, Japan, and '3epartment of Neurobiology and Anatomy and The Neuroscience Program, Wake Forest University School of Medicine, Winston- \\ Salem, North Carolina 27103
}

Glial cell line-derived neurotrophic factor (GDNF) regulates multiple aspects of spinal motoneuron (MN) development, including gene expression, target selection, survival, and synapse elimination, and mice lacking either GDNF or its receptors GDNF family receptor $\alpha 1$ (GFR $\alpha 1$ ) and Ret exhibit a 25\% reduction of lumbar MNs at postnatal day 0 (P0). Whether this loss reflects a generic trophic role for GDNF and thus a reduction of all MN subpopulations, or a more restricted role affecting only specific MN subpopulations, such as those innervating individual muscles, remains unclear. We therefore examined MN number and innervation in mice in which Ret, GFR $\alpha 1$, or GDNF was deleted and replaced by reporter alleles. Whereas nearly all hindlimb muscles exhibited normal gross innervation, intrafusal muscle spindles displayed a significant loss of innervation in most but not all muscles at P0. Furthermore, we observed a dramatic and restricted loss of small myelinated axons in the lumbar ventral roots of adult mice in which the function of either Ret or GFR $\alpha 1$ was inactivated in MNs early in development. Finally, we demonstrated that the period during which spindle-innervating MNs require GDNF for survival is restricted to early neonatal development, because mice in which the function of Ret or GFR $\alpha 1$ was inactivated after P5 failed to exhibit denervation of muscle spindles or MN loss. Therefore, although GDNF influences several aspects of MN development, the survival-promoting effects of GDNF during programmed cell death are mostly confined to spindle-innervating MNs.

Key words: motoneuron; trophic; GDNF; fusimotor; innervation; axon; spindle; neuromuscular

\section{Introduction}

Neurotrophic factors (NTFs) regulate the survival of discrete subpopulations of spinal motoneurons (MNs) during developmental programmed cell death (PCD) and in response to injury or neurodegeneration (Henderson, 1996; Gould and Oppenheim, 2006). The precise identity of these MN subpopulations, however, remains unclear. In theory, all subtypes of MNs, such as those projecting to individual muscles, could be reduced by a similar percentage in response to NTF deprivation, an idea consistent with the neurotrophic hypothesis, which states that ratelimiting amounts of NTF regulate MN survival (Purves, 1986; Korsching, 1993). In contrast, the reported 25-40\% loss of MNs observed in NTF mutants may reflect the complete loss of specific MN subtypes. Glial cell line-derived neurotrophic factor (GDNF), which together with other members of the GDNF fam-

Received Nov. 22, 2007; revised Dec. 18, 2007; accepted Dec. 31, 2007.

This work was supported by RIKEN and Ministry of Education, Culture, Sports, Science and Technology "The Project for Realization of Regenerative Medicine" (H.E.), National Institutes of Health Grant NS053527 (R.W.O.), and The Robert Packard Center for ALS Research (T.W.G., R.W.O.). We thank Kazuyo Misaki and Yukinao Shibukawa for their assistance with semithin processing and Ret point mutant construction, respectively.

Correspondence should be addressed to either of the following: Hideki Enomoto, Laboratory for Neuronal Differentiation and Regeneration, RIKEN Center for Developmental Biology, 2-2-3 Minatojima-Minamimachi, Chuo-ku, Kobe 650-0047, Japan, E-mail: enomoto@cdb.riken.jp; or Thomas W. Gould at his present address: Oceania University Building, National Health Complex, Moto'otua, P.0. Box 232, Apia,Samoa, E-mail:tom.gould@oceaniamed.org. DOI:10.1523/JNEUROSCI.5185-07.2008

Copyright $\odot 2008$ Society for Neuroscience $\quad$ 0270-6474/08/282131-16\$15.00/0 ily ligands (GFLs) signal through a receptor complex comprising GFL-specific coreceptors (GFR $\alpha$ ) and the RET tyrosine kinase, is a potent NTF that regulates the survival of MNs during PCD (Henderson et al., 1994; Oppenheim et al., 1995; Moore et al., 1996; Sánchez et al., 1996; Cacalano et al., 1998; Garcès et al., 2000; Oppenheim et al., 2000; Whitehead et al., 2005). Recently, GDNF signaling has also been shown to regulate other aspects of MN development, including the expression of subtype-specific transcription factors, motor axon projection, and muscle innervation (Garcès et al., 2000; Haase et al., 2002; Livet et al., 2002; Kramer et al., 2006). Therefore, the loss observed at postnatal day 0 (P0) in GDNF ligand/receptor knock-out (KO) mice may reflect the elimination of these subtypes of MNs in addition to or instead of the death of MNs, which require GDNF trophic signaling during PCD.

Two technical limitations have hindered the examination of this question: namely, the difficulty in estimating MN number precisely and therefore the number and identity of MNs expressing Ret and GFR $\alpha 1$, and the lethality of GDNF ligand/receptor KOs at $\mathrm{P} 0$ because of the absence of kidneys and enteric neurons. Here, we demonstrate that the numbers of lumbar MNs at P0 by in situ hybridization to the cholinergic marker vesicular acetylcholine transporter (VAchT) are mostly equivalent to the numbers of motor axons in adult L1-L6 ventral roots, thus allowing for precise quantification of Ret- and GFR $\alpha 1$-positive lumbar 
MNs during development. We also examined the axonal projections of each of these subtypes of MNs in mice in which one copy of Ret or GFR $\alpha 1$ expression was replaced by green fluorescent protein (GFP) or a chimeric tau-LacZ protein. Finally, we generated mice in which the function of either GFR $\alpha 1$ or Ret was conditionally inactivated in a $\mathrm{MN}$-specific or temporally specific manner, and in which recombination efficiency was $>90 \%$ as determined by GFP expression. Our analyses provide compelling evidence that the receptors for GFR $\alpha 1$ and Ret are expressed by all MNs during development and that the loss of MNs during PCD is mostly restricted to muscle spindle-innervating $\gamma$-MNs. We also show that the developmental period during which GDNF regulates the survival of $\gamma$-MNs is transient. These data demonstrate that the survival-promoting effects of a well characterized NTF are dramatically limited to a specific MN subtype.

\section{Materials and Methods}

Generation of Ret-TLZ mice. A $9.0 \mathrm{~kb} K p n I$ fragment containing the first coding exon of Ret was used to construct the targeting vector. The tautargeted lacZ (TLZ) cDNA followed by the Tn 5 neo cassette flanked with loxP sequences was inserted into the first coding exon by bacterial homologous recombination, removing 39 bp that encompass the first methionine and the following 6 aa of the signal peptide. The TLZ cDNA encodes a fusion protein composed of the $\mathrm{N}$-terminal region of bovine tau and full-length $\beta$-galactodisase. The vector was transfected by electroporation into RW-4 embryonic stem cells and homologous recombinants were identified by Southern blot hybridization. Properly targeted ES cell clones were injected into blastocysts to generate chimeric mice that successfully achieved germ-line transmission of the targeted allele. Heterozygous animals grew normally and were further crossed with $\beta$-actin Cre transgenic mice (Meyers et al., 1998) to remove the Tn5 neo cassette, thereby generating the knock-in allele referred to as $\operatorname{Ret}^{(T L Z /+)}$. Genotypes of $\operatorname{Ret}^{(T L Z /+)}$ mice were determined by Southern blotting or PCR using primers P1 (5' -CAGCGCAGGTCTCTCATCAGTACCGCA3'), P2 (5'-ACGTCGCTTTCGCCATCGCCCGTGCGC-3'), and P3 (5' AGGGCGAGGACAGTAGAGGGAGGCA-3 $)\left(94^{\circ} \mathrm{C}, 30 \mathrm{~s} ; 65^{\circ} \mathrm{C}, 30 \mathrm{~s}\right.$; $72^{\circ} \mathrm{C}, 60 \mathrm{~s} ; 35$ cycles), where wild-type (WT) and mutant alleles were amplified with P1-P2 (228 bp PCR product) and P1-P3 (300 bp PCR product) primer pairs, respectively.

Generation of floxed Ret mice. A $9.0 \mathrm{~kb} \mathrm{KpnI} \mathrm{fragment} \mathrm{containing} \mathrm{the}$ first coding exon of Ret was used to construct the targeting vector. A gene cassette composed of the floxed human Ret9 cDNA-SV40 intron-poly $(A)$ sequence, followed by the $C F P-p o l y(A)$ sequence and the FRT siteenclosed Tn5 neo sequence, was introduced into the first coding exon, removing $39 \mathrm{bp}$ nucleotides that encompass the first methionine and the following 6 aa of the signal peptide. The deletion disrupts the expression of the endogenous Ret gene but allows the expression of the inserted gene (Enomoto et al., 2004). The heterozygote floxed Ret allele, referred to as $\operatorname{Ret}^{f l o x /+}$, was generated using embryonic stem cell-based homologous recombination, and chimeric mice that successfully achieved germline transmission of the targeted allele were crossed to ACTB-Flpe transgenic mice (Rodriguez et al., 2000) in order to remove the FRT-enclosed neo cassette. The genotypes of mice carrying floxed Ret were determined by PCR using oligonucleotides P1 (5'-CTTCCAGGTTGGGTCGGAACTGAACCC-3') and P2 (5'-TGGCAGCACGAAGTACAGAGTGGCTAGGAACAT- $3^{\prime}$ ), where wild-type and mutant alleles generate 280 and 310 bp PCR products, respectively. PCR primers used to genotype Ret CFP-knock-in alleles were similar to those for Ret-TLZ mice, except that cyan fluorescent protein (CFP)-specific P3 (5'-TCGCCGGACACGCTGAACTTG-3') was used for detecting the mutant allele. Heterozygous mice ubiquitously expressing the Ret CFP knock-in allele $\left(\operatorname{Ret}^{\mathrm{CFP} /+}\right)$ were obtained by crossing $\operatorname{Ret}^{\text {flox/+ }}$ mice to $\beta$-actin-Cre mice. Ret ${ }^{\text {CFP/CFP }}$ mice, generated by crossing these mice to themselves, displayed a phenotype, including the absence of kidneys, identical with that of Ret $^{-/-}$mice (Enomoto et al., 2001) (data not shown).

For MN-specific inactivation of Ret or GFRa1, Ret flox/flox mice (above) or GFRat flox/flox mice (Uesaka et al., 2007) were crossed to Ret or GFR $\alpha 1$

\section{Table 1. Number of VAchT mRNA-positive lumbar MNs at P0.5}

\begin{tabular}{|c|c|}
\hline & No. of VAchT mRNA-positive lumbar MNs \\
\hline $\operatorname{Ret}^{+/+}$ & $3963 \pm 150(n=4)$ \\
\hline $\operatorname{Ret}^{\text {CFP/CFP }}$ & $3028 \pm 49(n=4)^{a}$ \\
\hline $\operatorname{Ret}^{\text {CFP/CFP }}$ & $2405 \pm 246(n=4)^{b}$ \\
\hline $\mathrm{GFR} \alpha 1^{\text {TLZ/TLZ }}$ & $3055 \pm 35(n=3)^{a}$ \\
\hline GDNF $^{\text {acZZ/lacZ }}$ & $3093 \pm 211(n=3)^{a}$ \\
\hline $\operatorname{Ret}^{Y 1062 F / Y 1062 F}$ & $2680 \pm 244(n=3)$ \\
\hline $\operatorname{Ret}^{Y 1015 F / Y 1015 F}$ & $3863 \pm 206(n=3)$ \\
\hline $\operatorname{Ret}^{Y 1015 F, Y 1062 F / Y 1015 F, Y 1062 F}$ & $2893 \pm 205(n=3)$ \\
\hline NT-3 $3^{\text {lacZ/lacZ }}$ & $3045 \pm 154(n=6)$ \\
\hline HB9-Cre;Ret ${ }^{\text {flox/TLZ }}$ & $3040 \pm 60(n=3)$ \\
\hline
\end{tabular}

${ }^{a}$ No peroneal deficit.

${ }^{b}$ Complete peroneal deficit.

heterozygous mice $\left[\operatorname{Ret}^{T L Z /+}\right.$ (above); or GFR $\alpha 1^{+/-}$(Enomoto et al., 1998)] expressing Cre recombinase under the control of the HB9 promoter (HB9-Cre) (Arber et al., 1999) (a kind gift from S. Arber, Biozentrum, Basel, Switzerland), referred to as HB9-Cre; $\mathrm{Ret}^{+/-}$or HB9-Cre; $G F R \alpha 1^{+/-}$. MN-specific knock-out progeny from these crosses are referred to as HB9-Cre; Ret flox/- or HB9-Cre; GFR $\alpha f^{\text {flox/- }}$. For time-

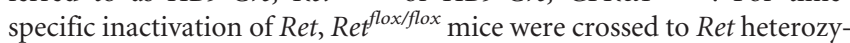
gous mice $\left(R e t^{T L Z /+}\right)$ ubiquitously expressing inducible Cre recombinase (CAGGCre-ER; The Jackson Laboratory, Bar Harbor, ME) (Hayashi and McMahon, 2002), referred to as CAGGCre-ER; Ret $^{+/-}$. Cre activity was induced in CAGGCre-ER; $R_{e} t^{T L Z / f l o x}$ mice by daily intraperitoneal injection of 4-hydroxytamoxifen (4-OHT) (0.1 mg per mouse; Sigma, St. Louis, MO) from P5 to P10. Conditional mutant mice used for all Cre-mice studies were kept on a mixed 129/Sv $\times$ C57BL/6 background.

Generation of point mutant Ret mice. For construction of point mutant Ret mice, mutations were introduced into human full-length Ret $9 \mathrm{cDNA}$ such that tyrosine $(\mathrm{Y})$ residues 1015,1062 , or 1015/1062 were converted to phenylalanine (F). WT and mutant Ret $9 \mathrm{cDNAs}$ were inserted into the Ret locus by gene targeting as described previously (Enomoto et al., 2001; Jain et al., 2006), resulting in the generation of a series of Ret knock-in

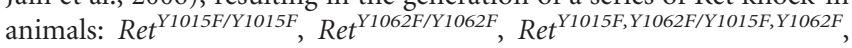
Ret $^{\text {Ret } 9 W T / R e t 9 W T}$ mice.

Other mice. GFR $\alpha 1^{T L Z /+}$ mice, in which TLZ was knocked into the GFR $\alpha 1$ locus (Enomoto et al., 1998), were used to follow the gross motor innervation pattern of hindlimb muscles. GDNF $F^{\text {lacZ/+ }}$ mice (Moore et al., 1996) (a kind gift from V. Pachnis, National Institute for Medical Research, London, UK) were used to track expression of GDNF in the neuromuscular system by X-Gal staining (below) in heterozygote and KO mice. NT3 ${ }^{\text {lac } /+}$ mice (Farinas et al., 1996) (a kind gift from J. Kucera, Boston University, Boston, MA) were used to count the number of MNs and examine the trajectory of motor axons in heterozygote and knockout mice. Mice were cared for according to the RIKEN Center for Developmental Biology institutional guidelines.

Histological analyses. Muscles were dissected and placed in blocking buffer (10\% FBS, 10\% normal horse serum, 1\% Triton X-100 in $0.1 \mathrm{M}$ $\mathrm{PBS})$ and incubated overnight $(\mathrm{ON})$ at $4^{\circ} \mathrm{C}$ with the following antibodies: chick anti-GFP (Aves Laboratories, Tigard, OR), rabbit anti-GFP (Invitrogen, Carlsbad, CA), rabbit anti-parvalbumin (PV) (Swant, Bellinzona, Switzerland), goat anti-VAchT (Chemicon, Temecula, CA), rabbit anti-Neurofilament-200 $\mathrm{kDa}(\mathrm{xNF})$ (Chemicon), rabbit anticalbindin (CB) (Swant), goat anti- $\beta$-galactosidase ( $\beta$-gal) (AbD Serotec, Raleigh, NC). For sections of spinal cord, ventral root, and muscles, similar procedures were also followed with antibodies against GFP, PV, NF, VAchT, $\beta$-gal, rabbit anti-HB9 (kindly provided by Sam Pfaff, Salk Institute, San Diego, CA), $\alpha 3 \mathrm{Na}^{+} / \mathrm{K}^{+}$ATPase ( $\alpha 3 \mathrm{NKA}$ ) (Upstate Biotechnology, Lake Placid, NY), mouse Ret (Neuromics, Edina, MN), human Ret (Neuromics), and activated caspase-3 (Cell Signaling, Danvers, MA). Muscles or sections were rinsed and then incubated in fluorescent secondary antibodies and/or Cy3- or Cy5- $\alpha$-bungarotoxin (Invitrogen), rinsed, mounted in $15 \%$ glycerol, and imaged under a confocal microscope (LSM5, Pascal System; Zeiss Microimage, Tokyo, Japan).

For whole-mount 5-bromo-4-chloro-3-indolyl- $\beta$-D-galactopyrano- 


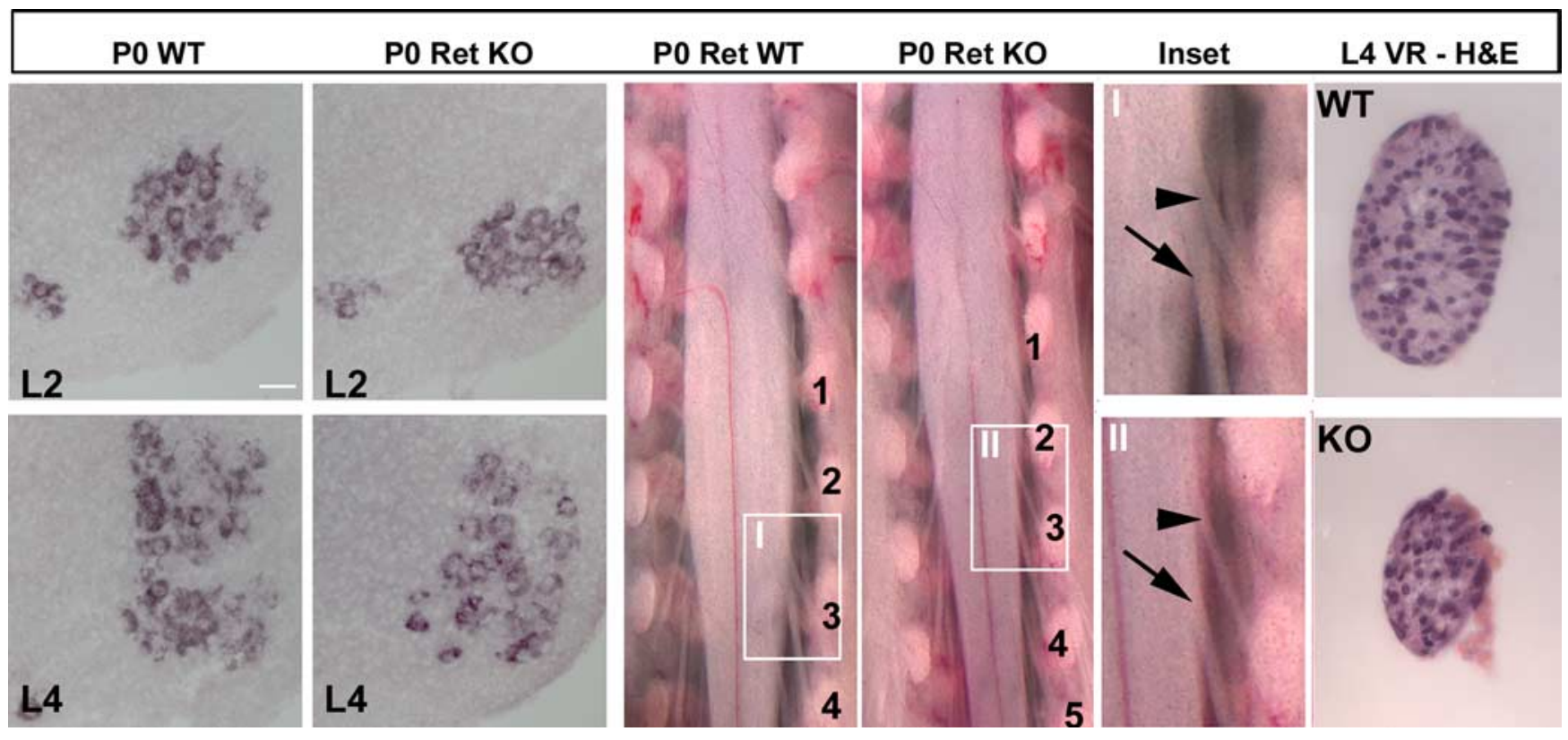

Figure 1. The loss of MNs in GDNF ligand/receptor KO mice is distributed throughout the lumbar spinal cord. The number of VAchT mRNA-positive MNs is reduced in cross sections taken from various rostrocaudal regions of the lumbar spinal cord in PO Ret KO mice, versus control (left four panels). L2 and L4, Lumbar segments 2 and 4 based on ventral root (VR) exit position. Scale bar, 50 $\mu \mathrm{m}$. The diameter of VRs is reduced in ventral laminectomized preparations of PO Ret KO lumbar spinal cords versus control (middle four panels). The numbers refer to lumbar vertebrae. The inset boxes show enlarged images of L3 and L4 VRs (arrowheads and arrows, respectively). Scale bar, $500 \mu \mathrm{m}$. Niss--stained ventral roots show the reduction of axonal diameter in the L4 VR of PO Ret KO mice (right, bottom panel) versus control (right, top panel). Scale bar, $10 \mu \mathrm{m}$.

side (X-gal) staining, embryos were fixed in $0.2 \%$ glutaraldehyde, $5 \mathrm{~mm}$ EGTA, $2 \mathrm{~mm} \mathrm{MgCl}_{2}$, and $0.1 \mathrm{M} \mathrm{PB}$, pH 7.2, for $30 \mathrm{~min}$ at $4^{\circ} \mathrm{C}$ and incubated in the dark on a rotator in $\mathrm{X}$-gal staining solution $\mathrm{ON}$ at room temperature (RT). Some embryos were subsequently dehydrated in sequential methanol:PBS rinses, treated with $3 \% \mathrm{H}_{2} \mathrm{O}_{2}$ for $2 \mathrm{~h}$ at RT, rehydrated in methanol:PBS rinses, blocked overnight in 10\% DMSO, $5 \%$ dry milk, $1 \%$ Triton X-100, 1\% Tween 20 in PBS, incubated with antibodies against GFP or NF in blocking solution for $1-3 \mathrm{~d}$ at $\mathrm{RT}$, rinsed, incubated with biotinylated secondary antibodies $(1 / 500) \mathrm{ON}$ at $4^{\circ} \mathrm{C}$, rinsed, incubated with peroxidase-conjugated streptavidin $(1 / 1000)$ for $3 \mathrm{~h}$ at RT, rinsed and treated with diaminobenzidine $(5 \mu \mathrm{g} / \mathrm{ml})$ for $15 \mathrm{~min}$ at RT in the dark, before being dehydrated in methanol and cleared in 2:1 (v/v) benzyl benzoate:benzyl alcohol.

In situ hybridization with the probe against the mouse VAchT was used to quantify the number of lumbar MNs as previously described (Gould et al., 2006). Our estimates, as well as the highly similar results generated by adult ventral root axon counts (Biscoe et al., 1982), may nevertheless overestimate the correct number, because our counts were taken at $\mathrm{P} 0$ and therefore do not reflect the small amount of postnatal MN death that occurs (Oppenheim et al., 1986), whereas the counts of Biscoe et al. (1982) include the small amount of lumbar medial motor column MNs that innervate trunk musculature (which we estimate to be $<250$ by VAchT mRNA counts). The sections were counterstained with Hoechst 33342 and MNs were counted as mRNA-positive cells whose nucleus was within the plane of section and contained at least two nucleoli. The appearance and disappearance of laterally appearing HB9immunoreactive MNs was used as a marker for estimating the rostrocaudal limits of the lumbar spinal cord at early embryonic ages. We then labeled adjacent sections with antibodies against activated caspase- 3 and Hoechst 33342 to quantify dying MNs.

Myelinated axons from P42 mice were counted in 1- $\mu$ m-thick, toluidine blue-stained sections after fixation in $2 \%$ paraformaldehyde $/ 2 \%$ glutaraldehyde/cacodylate buffer and postfixation in $2 \%$ osmium tetroxide. Counts of myelinated axons were performed as previously reported (Gould et al., 2006), with axons whose diameter was $<4$ or $>4 \mu \mathrm{m}$ labeled "small" or "large," respectively.

\section{Results}

To identify the subpopulation(s) of MNs that require GDNF for survival during PCD, we first developed a method to accurately measure the number of MNs at P0, the age at which GDNF ligand/receptor mutants die. We generated a riboprobe against the VAchT, which labels all cholinergic neurons including MNs. In contrast to estimates of lumbar MN number by Nissl labeling, which vary widely in the literature and range from 2000 to 4000 MNs (Oppenheim et al., 2001; Holtmann et al., 2005), the number of lumbar MNs by in situ hybridization with the VAchT probe yielded estimates with limited variability and in accord with the number of lumbar ventral root axons in adult mice (3963 \pm 15 ; $n=4$; vs $3952 \pm 63$ ) (Biscoe et al., 1982). Quantification of the number of lumbar MNs by VAchT mRNA-labeling in GDNF, GFR $\alpha 1$, and Ret null mutant mice at P0 revealed that the loss of MNs was 22-25\% (Table 1), similar to previously published counts of lumbar MN cell bodies (Moore et al., 1996; Sánchez et al., 1996; Cacalano et al., 1998; Oppenheim et al., 2000) and axons (Buss et al., 2006) in GDNF or GFR $\alpha 1$ mutants. To determine whether this loss was restricted to spatial subpopulations or distributed across the entire lumbar spinal cord, we examined the number of VAchT mRNA-labeled MNs at different axial levels of the lumbar spinal cord in P0 Ret WT and null mutant (KO) mice. We observed fewer labeled MNs at every level as well as a marked reduction in the diameter of each lumbar ventral root in Ret KOs (Fig. 1), in accord with the results of a previous study (Oppenheim et al., 2000). Because it was recently shown that the peroneal nerve exhibited severe growth deficits in a subset of GDNF ligand/receptor KOs (Kramer et al., 2006), we wanted to compare the number of MNs of Ret KO mice in which the development of this nerve was most severely disrupted to those of Ret KO mice in which it was normal. We found that the most severely affected mutants, in which the peroneal nerve was completely missing at 

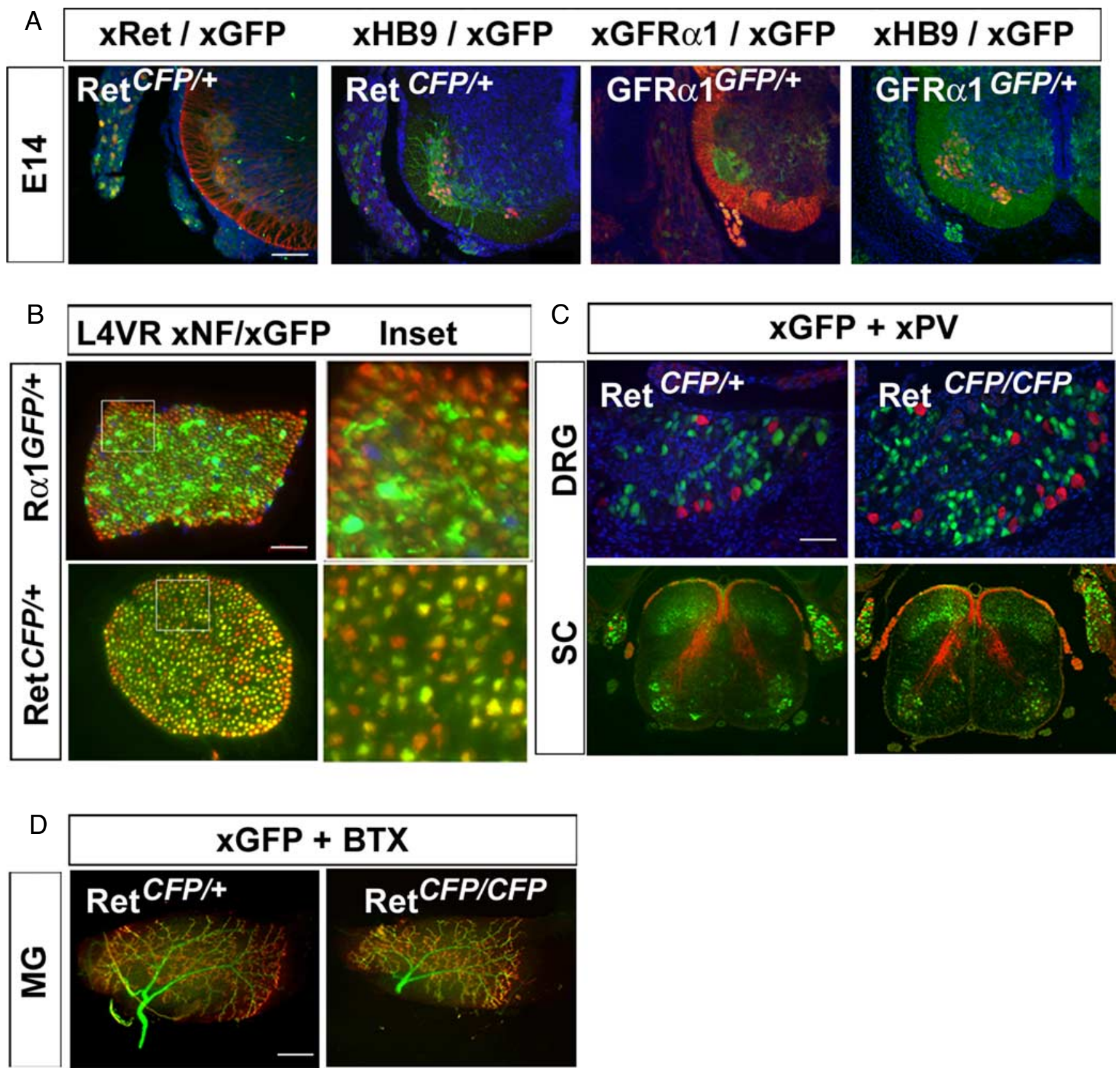

Figure 2. GFP is expressed by MNs in Ret ${ }^{C F P /+}$ and GFR $\alpha 1^{G F P /+}$ knock-in mice.A, Cross sections of the lumbar spinal cord near the peak of the MN cell death period (E14) show that GFP in Ret ${ }^{C F P /+}$ (left two panels) and in GFR $\alpha 1^{G F P /+}$ (left two panels) is robustly expressed HB9-immunoreactive motor column (second and fourth panels), as well as by Ret-immunoreactive (first panel) and GFR $\alpha 1$-immunoreactive cells (third panel). B, Cross sections of the L4 VR in P30 Ret ${ }^{\mathrm{CFP} /+}$ (bottom panels) and P30 GFR $\alpha 1^{G F P /+}$ (R $\alpha 1^{G F P /+}$; top panels) mice demonstrate the high percentage of neurofilament-immunoreactive (xNF) axons (red) that express GFP (green). Note the expression of GFP in xNF-negative Schwann cells of GFR $\alpha 1^{G F P /+}$ but not Ret ${ }^{C F P /+}$ VRs. Scale bars: $A, B, 50 \mu \mathrm{m}$. C, The cell bodies (top panels) and central processes (bottom panels) of PV-positive proprioceptive sensory neurons (red) fail to express GFP immunoreactivity (green) and thus Ret in PO Ret ${ }^{C F P /+}$ and Ret $^{C F P / C F P}$ mice (left and right panels, respectively). DRG, Dorsal root ganglia; SC, spinal cord. D, Whole-mount staining of GFP-immunoreactive motor axons (green) and Cy3- $\alpha$-bungarotoxinlabeled $(\alpha-B T X)$ nAChRs (red) demonstrates that the gross motor innervation of the medial gastrocnemius (MG) is unaffected in Ret ${ }^{C F P /(F P}$ mice (right panel), versus Ret ${ }^{C F P /+}$ mice. Scale bars: $C, D$, $200 \mu \mathrm{m}$.

P0 (see Fig. 3) (see below), exhibited an additional reduction of $\sim 600$ lumbar MNs (Table 1) $(p=0.00971)$, a result approximately similar to the number of $\mathrm{MNs}$ in the rat peroneal motor pool (457 \pm 21 ) (Yeong et al., 1998). These data suggest that MNs that depend on GDNF for survival during PCD include the peroneal subtype that is localized into a spatially restricted motor pool and another subtype(s) that is distributed throughout the entire lumbar spinal cord.

We next tested whether all lumbar MNs expressed GDNF receptors at the beginning of the cell death period [embryonic day 12.5 (E12.5)]. In agreement with the results of Garcès et al. (2000), we found that nearly all MNs in WT mice expressed both Ret and GFR $\alpha 1$ mRNA (data not shown). Furthermore, similar to Haase et al. (2002), we found by quantitative HB9 immunostaining that the number of lumbar MNs per section at E12.5 was similar in WT and GDNF ligand/receptor KO mice (data not shown). Together, these results demonstrate that the increased loss of MNs observed in $\mathrm{KO}$ mice at $\mathrm{P} 0$ is not caused by differential receptor expression or by a reduction of MNs before the cell death period. 


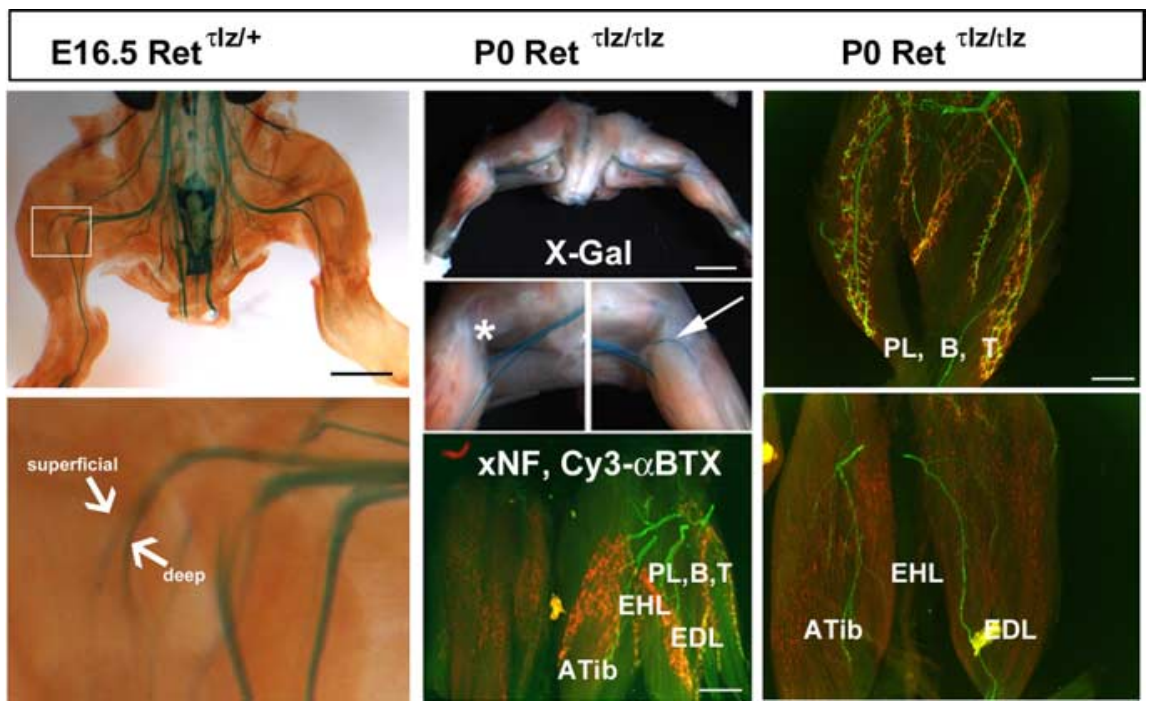

Figure 3. The peroneal motor innervation deficit observed in GDNF ligand/receptor K0 mice results in one of three phenotypes at P0. Left panels, Whole-mount X-Gal staining of hindlimbs from E16.5 heterozygous mice expressing TLZ in the Ret locus (Ret ${ }^{T L Z /+}$ mice) shows the divergence of the peroneal nerve into superficial and deep branches. Scale bar, $500 \mu \mathrm{m}$. Middle panels, Whole-mount X-Gal-stained hindlimbs of PO Ret ${ }^{T L Z T L Z}$ mice (middle top panels) demonstrate the absence or presence of the peroneal nerve (asterisk vs arrowhead) in individual Ret hindlimbs. Whole-mount xNF, $\alpha$-BTX costaining of PO Ret $^{T L Z / L Z}$ mice (middle bottom panel) show the corresponding absence or presence of terminal innervation of the six peroneal muscles. Note the absence of clustered nAChRs in denervated peroneal muscles of Ret KOs (left shank, middle bottom panel). PL, Peroneus longus; $\mathrm{PB}$, peroneus brevis; PT, peroneus tertius; EDL, extensor digitorum longus; EHL, extensor hallucis longus; ATib, tibialis anterior (cranialis). Scale bars: Top panel, $1000 \mu \mathrm{m}$; bottom panel, $200 \mu \mathrm{m}$. Right panels, Whole-mount xNF, $\alpha$-BTX costaining of deep (top) or superficial (bottom) peroneal muscles of PO Ret ${ }^{T I Z T L Z}$ mice shows that a subtype of Ret KOs exhibit normal deep but severely reduced superficial peroneal muscle staining. Note the presence of axons entering these muscles associated with partially but not completely clustered nAchRs (bottom right panel). Scale bar, $100 \mu \mathrm{m}$.

MN subtypes can be categorized according to a variety of properties including transcriptional profile, location within the spinal cord, and muscle target subtype (Price and Briscoe, 2004). Because the population of MNs innervating specific muscles, known as motor pools, can be easily measured by a variety of techniques, we chose to examine whether selective deficits in motor pool innervation contributed to the rostrocaudally distributed loss of lumbar MNs in GDNF ligand/receptor KOs. To track the innervation of Ret and GFR $\alpha 1$-positive MNs during the course of MN PCD, we generated conditional knock-in mice in which the expression of Ret or GFR $\alpha 1$ can be replaced by the expression of CFP or GFP, respectively (supplemental Fig. 1, available at www.jneurosci.org as supplemental material) (Uesaka et al., 2007). After crossing these mice to mice expressing Cre recombinase under the $\beta$-actin promoter, Ret or GFR $\alpha 1$ was deleted in one allele in all cells including the germ line; these mice were maintained as Ret or GFR $\alpha 1$ heterozygotes and crossed with themselves to yield conventional null mutants. At E14, near the peak of MN PCD, immunostaining with antibodies against GFP in these heterozygote animals (hereafter called $\mathrm{Ret}^{\mathrm{CFP} /+}$ or GFR $\alpha 1^{G F P /+}$ ) revealed robust expression of the reporter allele in HB9-positive MNs (Fig. 2A). Similar expression was detected in $>90 \%$ of L 4 motor axons of P30 Ret ${ }^{C F P /+}$ or GFR $\alpha 1^{G F P /+}$ mice, as well as in Schwann cells of GFR $\alpha 1^{G F P /+}$ mice (Fig. $2 B$ ), consistent with previous reports of GFR $\alpha 1$ but not Ret in these cells (Naveilhan et al., 1997; Trupp et al., 1997). These data demonstrate the successful generation of $\operatorname{Ret}^{\mathrm{CFP} /+}$ or GFR $\alpha 1^{\mathrm{GFP} /+}$ mice and indicate their utility for measuring the pattern of gross muscle innervation by GFP immunohistochemistry.

To analyze the peripheral projection of GFP-immunoreactive axons to individual hindlimb muscles at $\mathrm{P} 0$, we took advantage of the following observation. When we colabeled cross-sections of the spinal cord and dorsal root ganglion of these mice with antibodies to GFP and parvalbumin, we observed that proprioceptive sensory afferent neurons that express PV fail to express Ret (Fig. 2C), consistent with the previously reported finding that large-diameter spinal sensory afferent neurons lack Ret mRNA (Baudet et al., 2000). Therefore, because GFP immunostaining in the hindlimb of Ret $^{\text {CFP/+ }}$ mice reflects motor and not sensory innervation, we focused our analysis on $\operatorname{Ret}^{C F P /+}$ or $\operatorname{Ret}^{T L Z /+}$ mice, to avoid potentially confounding Schwann cell- and limb-derived staining in GFR $\alpha 1$ knock-in mice (Enomoto et al., 2004; Gould and Oppenheim, 2004). Whole-mount staining of the medial gastrocnemius muscle in both animals shows that the gross motor innervation of this muscle is unaffected in Ret KOs, although the overall size of the muscle is reduced (Fig. 2D). We performed similar staining on $\sim 35$ hindlimb muscles at P0 and found that nearly all of them exhibited normal innervation of extrafusal $\alpha$-bungarotoxin- ( $\alpha$-BTX)-colabeled nicotinic acetylcholine receptor (nAchR) clusters in Ret KO mice (supplemental Figs. 2, 3 , available at www.jneurosci.org as supplemental material). However, three muscle groups exhibited aberrant motor innervation in these mice: the peroneal muscles, the gluteus maximus and tensor fascia latae, and the iliopsoas. We next describe each of these deficits.

Consistent with the results of Kramer et al. (2006), who found that the peroneal nerve, which branches into the deep and superficial peroneal nerves, was severely affected at E12.5 in GDNF ligand/receptor mutants, we observed that the three deep and three superficial peroneal muscles were totally lacking innervation in a subset of Ret KO mice (Fig. 3). Interestingly, we found that this severe phenotype was observed in only $42 \%$ of Ret KOs, whereas the remaining 58\% exhibited either completely normal innervation of all six peroneal muscles, or impaired innervation of the superficial three but not deep three peroneal muscles (Table 2, Fig. 3). These three different peroneal muscle innervation outcomes at $\mathrm{P} 0$ are in accord with the variable severity at E12.5 of the peroneal nerve deficit (Kramer et al., 2006). The most severe deficit results in the complete absence of the peroneal nerve at $\mathrm{P} 0$, as indicated by X-gal staining of $\operatorname{Ret}^{T L Z / T L Z}$ hindlimbs, and the corresponding lack of both motor and sensory innervation of the peroneal muscles. In contrast, when the deficit affects only the superficial muscles, sensory innervation of muscle spindles is detectable by PV immunostaining (data not shown), indicating that the impairment of motor innervation of these muscles is related to a distal growth or arborization deficiency, similar to that of MNs innervating the latissimus dorsi (LD) and cutaneus maximus (CM) muscles (Haase et al., 2002). In all cases of impairment, the affected muscles exhibit gross atrophy and a failure to cluster $\alpha$-BTX-labeled nAchRs (Fig. 3).

The second gross innervation deficit in Ret KOs affected the superior gluteal nerve (SGN), which sends two branches to the gluteus minimus and gluteus profundis and a third branch that 
Table 2. Percentage of hindlimbs exhibiting normal motor innervation at PO

\begin{tabular}{|c|c|c|c|c|c|c|c|c|}
\hline & Peroneal $^{a}[\%(n)]$ & Deep peroneal $^{b}(\%)$ & $\mathrm{EDL}^{b}(\%)$ & $\operatorname{ATib}^{b}(\%)$ & $\operatorname{GMax}^{b}(\%)$ & $\mathrm{TFL}^{b}(\%)$ & Psoas major ${ }^{b}[\%(n)]$ & Spindle $^{b}(\%)$ \\
\hline $\operatorname{Ret}^{+1+}$ & $100(n=40)$ & 100 & 100 & 100 & 100 & 100 & $100(n=5)$ & 100 \\
\hline $\operatorname{Ret}^{C F P /+}$ & $100(n=40)$ & 100 & 100 & 100 & 100 & 100 & $100(n=5)$ & 100 \\
\hline $\operatorname{Ret}^{C F P / C F P}$ & $58(n=86)$ & 58 & 55 & 23 & 47 & 3 & $0(n=4)$ & 0 \\
\hline $\mathrm{GFR} \alpha 1^{\text {TLZ/TLZ }}$ & $41(n=22)$ & 41 & 22 & 18 & 54 & 0 & $0(n=3)$ & 0 \\
\hline GDNF $^{l a c Z / l a c Z}$ & $56(n=18)$ & 56 & 45 & 29 & 44 & 0 & $0(n=3)$ & 0 \\
\hline $\operatorname{Ret}^{Y 1062 F / Y 1062 F}$ & $91(n=67)$ & 91 & 78 & 62 & 78 & 2 & ND & 0 \\
\hline $\operatorname{Ret}^{Y 1015 F / Y 1015 F}$ & $100(n=20)$ & 100 & 100 & 100 & 100 & 100 & ND & 100 \\
\hline $\operatorname{Ret}^{Y 1015 F, Y 1062 F / Y 1015 F, Y 1062 F}$ & $91(n=34)$ & 91 & 76 & 59 & 80 & 0 & ND & 0 \\
\hline HB9-Cre;Ret ${ }^{f l o x / T L Z}$ & $56(n=40)$ & 56 & 51 & 29 & 48 & 0 & $0(n=6)$ & 0 \\
\hline HB9-Cre;GFR $\alpha 1^{\text {flox/TLZ }}$ & $70(n=70)$ & 70 & 65 & 50 & 55 & 0 & ND & 0 \\
\hline
\end{tabular}

EDL, Extensor digitorum longus; ATib, tibialis anterior; ND, not determined.

${ }^{a}$ Nerve present.

${ }^{b}$ Normal motor innervation of muscle observed.

divides to innervate the superior one-half of the gluteus maximus (sGMax) and the tensor fascia latae (TFL) (Hebel and Stromberg, 1986). Whereas in Ret ${ }^{C F P /+}$ mice, in which GFP immunoreactivity is always observed in the SGN nerve and the two smaller branches that diverge to innervate these muscles, Ret ${ }^{\text {CFP/CFP }}$ mice often exhibit extremely weak staining of the SGN and no staining of the two smaller branches (Fig. 4A). Similar to the peroneal nerve, the SGN deficit is variable, in that some KO mice exhibit no staining of either branch, some display staining of the sGMax branch but not the TFL branch, and an extremely small subset of mice are unaffected (Table 2). In mice in which both small branches are missing, the inferior gluteal nerve (IGN) often compensates for the missing sGMax branch by innervating both the inferior and superior GMax instead of only the inferior portion (Fig. 4A). Similar to aneural peroneal muscles, TFL muscles failing to receive innervation are grossly atrophic and display unclustered nAchRs (data not shown). The sGMax/TFL deficit is also observed in GDNF and GFR $\alpha 1$ mutant mice and can be followed by lacZ staining in GFR $\alpha 1^{\text {TLZ/TLZ }}$ mice (Table 2, Fig. $4 B$ ). Innervation to the gluteus medius and profundis is normal in GDNF ligand/receptor KO mice (supplemental Figs. 2, 3, available at www.jneurosci.org as supplemental material).

The final gross motor innervation deficit in GDNF ligand/ receptor KOs affects the iliopsoas muscles, which include the psoas major and minor and iliacus muscles. The gross innervation of the iliacus, psoas minor, and anterior psoas major are completely unaffected, but the innervation of the posterior psoas major is missing in KOs (supplemental Fig. 4, available at www. jneurosci.org as supplemental material). Similar to the impaired innervation of the LD, CM, and TFL muscles, the posterior onehalf of the psoas major (pPMaj) is affected in nearly all mutants at P0 (Table 2). The absence of innervation to the posterior psoas major results in the atrophy of this muscle that is visible at $\mathrm{P} 0$ but becomes much more obvious in older animals (supplemental Fig. 4, available at www.jneurosci.org as supplemental material) (see description of conditional Ret and GFR $\alpha 1$ mutants below). With the exception of the most severe peroneal deficit, which affects $\mathrm{MN}$ growth or nerve selection at an early stage several days before distal arborization, the gross hindlimb innervation deficits affecting GDNF ligand/receptor KOs appear to result from a failure of motor axons to invade and/or arborize into the final target, similar to the previously described deficits affecting the LD and CM trunk muscles (Haase et al., 2002).

Because GDNF ligand/receptor KOs exhibiting completely normal peroneal innervation can be assumed to contain an approximately normal number of peroneal MNs (the nerves appear to be of similar size by GFP immunostaining in $\operatorname{Ret}^{C F P /+}$ and
Ret $^{\text {CFP/CFP }}$ mice at P0), and because the number of MNs lost in these animals $(\sim 1000)$ is significantly greater than what would be expected for the absence of MNs innervating the sGMax/TFL/ pPMaj muscles (Nicolopoulos-Stournaras and Iles, 1983; Gerrits et al., 1997), we continued to search for distal innervation deficits in these mutants using GFP staining, reasoning that the remaining MNs that were lost were distributed across many motor pools. Because MNs within most motor pools innervate extrafusal muscle fibers (skeletomotor or $\alpha$-MNs) or intrafusal muscle spindles (fusimotor or $\gamma$-MNs), we chose to examine the distal innervation of these two targets. We noticed that many muscles in $\operatorname{Ret}^{C F P /+}$ but not Ret ${ }^{C F P / C F P}$ mice contained GFPimmunolabeled axons that diverged from the major nerve branch, traveled parallel alongside several muscle fibers, and terminated onto nAChRs distal from the $\alpha$-BTX-labeled endplate band (for example, see the adductor magnus in supplemental Fig. 2, available at www.jneurosci.org as supplemental material). Subsequent whole-mount coimmunostaining with antibodies against GFP and PV, which forms characteristic annulospiral nerve terminal endings on the equatorial region of muscle spindles, confirmed that these GFP-labeled processes were fusimotor and not sensory axons, because they traveled with but did not colocalize to these PV-positive axons, and because they were apposed to nAChRs within polar regions of the spindles (Fig. 5B). To confirm that the GFP-labeled axons in these mice were cholinergic motor and not noradrenergic sympathetic fibers, which also innervate muscle spindles (Santini and Ibata, 1971), we obtained similar results with antibodies against PV and the cholinergic marker VAchT (Fig. 5A). Furthermore, we found that this pattern of fusimotor innervation was selectively missing in $\mathrm{P} 0$ Neurotrophin-3 (NT-3) KO mice (Fig. 5A), which exhibit a complete absence of proprioceptive sensory neurons and therefore muscle spindles (Ernfors et al., 1994; Tessarollo et al., 1994).

When we compared either VAchT/PV or GFP/PV staining between Ret ${ }^{C F P /+}$ and Ret ${ }^{C F P / C F P}$ mice, we could clearly identify that, whereas skeletomotor innervation of extrafusal nAChRs was unaffected, fusimotor innervation of muscle spindles was greatly reduced in Ret KOs (Fig. 5A-C). Although GFP-stained axons exhibited a number of processes growing toward the spindle and originating from proximal axons and neuromuscular junctions, VAchT immunoreactivity and $\alpha$-BTX-labeled nAchRs were usually missing near muscle spindles in Ret KOs (Fig. $5 A, B)$, suggesting that the remaining MNs cannot compensate for the missing $\gamma$-MNs. Although most muscles exhibited a large deficit in the number of motor-innervated muscle spindles, at least one muscle, the rectus femoris, appears normal in Ret KO mice at P0 (Fig. 5C). The total number of spindles per muscle, 


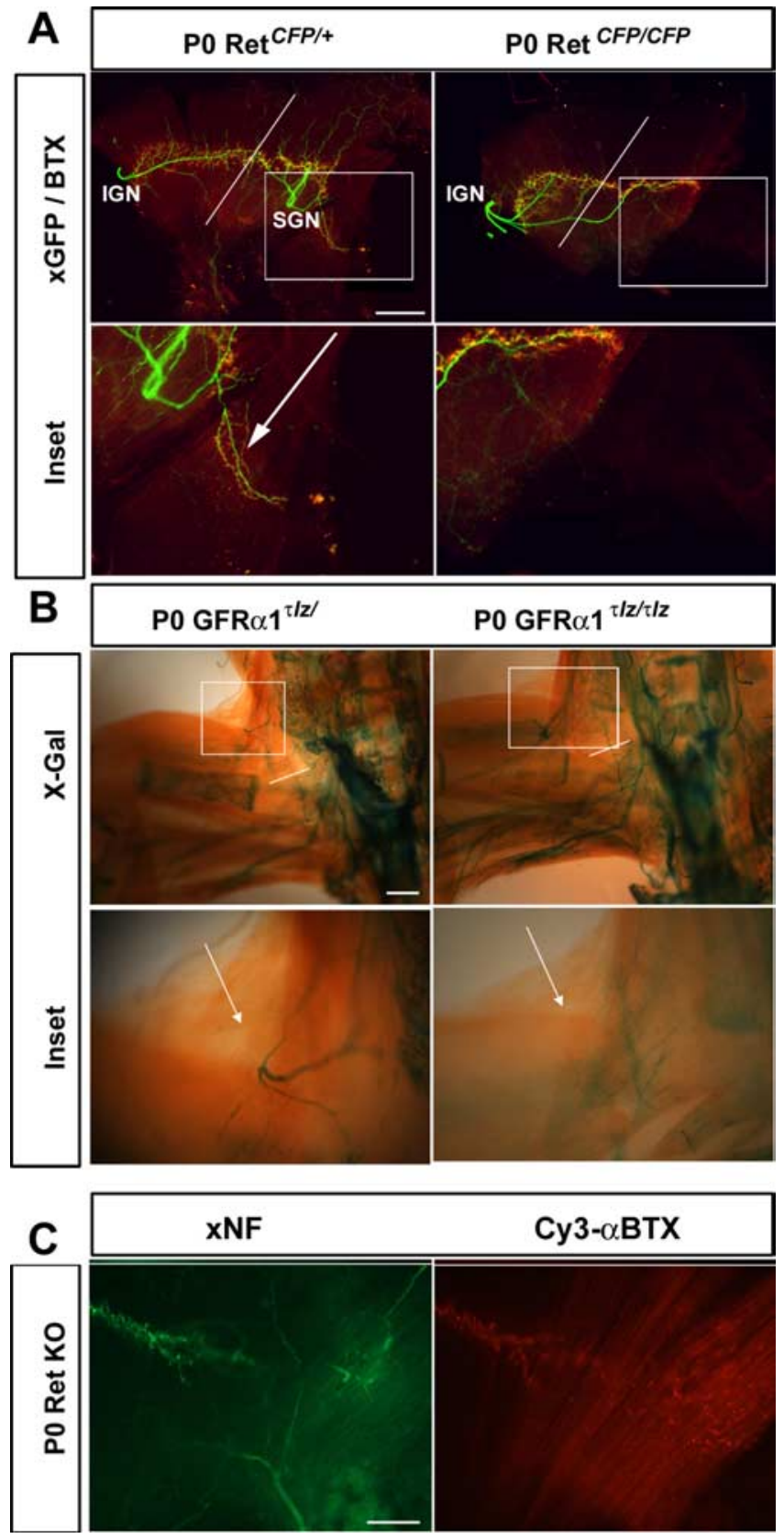

Figure 4. MNs fail to innervate the SGMax and TFL muscles in GDNF ligand/receptor KO mice. $A$, Whole-mount $x G F P, \alpha$-BTX costaining shows that the inferior and superior GMax normally receive separate innervation from the IGN and SGN, respectively, in PO Ret ${ }^{C F P /+}$ mice (left panels). The TFL receives a separate branch from the SGN (arrow in bottom left panel). In contrast, the SGN often fails to send branches to innervate the TFL and sGMax in PO Ret ${ }^{\text {CP/CFP }}$ mice (right panels). In a subset of KOs, the IGN compensates for this deficit by extending into and innervating the region of the $5 G M a x$ (but never the TFL) normally supplied by the SGN (right panels). Scale bar, $400 \mu \mathrm{m}$. $\boldsymbol{B}$, The sGMax/TFL deficit is also observed in GFR $\alpha 1$ KO mice expressing TLZ in the GFR $\alpha 1$ locus. Low- and high-power (top, bottom panels) images of whole-mount hindlimbs stained with X-gal show that the SGN nerve normally sends a major branch, which divides into two or three smaller branches, to innervate the SGMax, and a single branch which turns at $90^{\circ}$ to innervate the TFL (arrow in bottom left panel) in PO GFR $\alpha 1^{T L Z /+}$ mice. In contrast, PO GFR $\alpha 1^{T L Z / T L Z}$ mice are often missing the major SGN branch itself (bottom right panel). The white line in the top panels reflects termination point of IGN nerve. Scale bar, $1000 \mu \mathrm{m}$. C, Sensory axons stained with antibodies against neurofilament (xNF; green) innervate the sGMax in PO Ret $\mathrm{KO}$ mice but are incapable of clustering $\mathrm{nAChRs,} \mathrm{which} \mathrm{are} \mathrm{spread} \mathrm{throughout} \mathrm{this} \mathrm{portion}$ of the muscle (Cy3- $\alpha \mathrm{BTX})$. Scale bar, $100 \mu \mathrm{m}$. however, which could easily be measured by counting the number of fibers receiving xPV-stained processes in muscle whole mounts [e.g., $8 \pm 1$ vs $9 \pm 1$ in Ret WT vs KO in inferior gluteus maximus (iGMax); $n=5$ ] or in serial muscle sections (e.g., $13 \pm$ 2 vs $11 \pm 3$ in Ret WT vs KO in medial gastrocnemius; $n=5$ ), was not affected in Ret $\mathrm{KO}$ mice at P0. Additionally, we failed to detect any differences between Ret WT and Ret KO mice in the expression of EGR3 mRNA within spindles (data not shown). Finally, we observed similar fusimotor innervation deficits in GDNF and GFR $\alpha 1$ KOs (Table 2). These data suggest that the missing MNs in GDNF ligand/receptor mice include a significant number of spindle-innervating $\gamma$-MNs.

We next investigated the expression pattern of GDNF in the developing hindlimb of GDNF ${ }^{\text {LacZ/+ }}$ mice (Moore et al., 1996). We detected GDNF by whole-mount X-Gal staining of these mice in the dorsal limb bud at E11.5, just before the emergence of neurofilament-immunoreactive peroneal axons into this region (Fig. $6 \mathrm{~A}$ ), consistent with the possibility that GDNF in this region acts as a chemotropic signal for peroneal MNs (Kramer et al., 2006). In contrast, at later ages when the peroneal nerve branches can clearly be detected (E12.5 and older), we observed GDNF only in cells surrounding distal axon processes and never in the muscle targets themselves (Fig. 6A). In contrast, GDNF was highly expressed by all the iliopsoas and gluteal muscles at least as early as E15-E16, the first time point that these muscles could be clearly identified (Fig. 6A) (data not shown). These results suggest that the small distal innervation deficits of the sGMax/TFL/ pPMaj muscles in GDNF ligand/receptor KOs, similar to those of the LD and CM muscles in the trunk (Haase et al., 2002), are caused by the absence of final target-derived GDNF, whereas the early, profound peroneal nerve deficit is caused by the absence of intermediate target-derived GDNF. However, the distal innervation deficit of the superficial peroneal muscles is not associated with obvious GDNF expression in these muscles.

To determine whether GDNF expression was present within muscle spindles at any point during their innervation by MNs, we used antibodies against $\beta$-gal together with parvalbumin or GFP in developing $\operatorname{Ret}^{\text {CFP/+ }}$, GDNF ${ }^{\text {LacZ/+ }}$ hindlimb muscle. Sensory neurons innervating skeletal muscle begin to induce intrafusal muscle fibers at E15-E15.5 (Kucera et al., 1995b). Therefore, we looked at E15 muscle and noticed that GDNF was expressed not only in nascent muscle spindles (identified by the localization of PV-positive sensory terminals) but also in adjacent muscle fibers (Fig. 6B). At this time, motor axons stained with GFP antibodies in adjacent sections could also be seen elaborating processes around the GDNF-positive muscle spindle (Fig. 6B). At E17 and even more so at P0, GDNF expression was significantly elevated in spindles (Fig. $6 \mathrm{~B}$ ). These data suggest that GDNF expression is expressed by but not restricted to intrafusal muscle fibers during the earliest period of fusimotor innervation, and that the robust expression of GDNF within spindles at P0 previously observed by Whitehead et al. (2005) occurs later. Finally, because a physiologically important role for GDNF expression in both muscle and Schwann cells has been observed (Arce et al., 1998; Nguyen et al., 1998), we sought to characterize the onset of GDNF expression in these tissues during the earliest period of MN PCD. At E12.5, we could easily visualize $\beta$-gal immunoreactivity in hindlimb mesenchyme, Schwann cells, and floorplate of GDNF ${ }^{\text {LacZ/+ }}$ mice (Fig. $6 C)$. $\beta$-Gal-positive Schwann cell bodies were easily segregated from GFP-positive motor axons in the ventral root at these early time points in $\mathrm{Ret}^{\mathrm{CFP} /+}$, GDNF ${ }^{\mathrm{LacZ} /+}$ mice (Fig. $6 \mathrm{C}$ ). These studies demonstrate that GDNF is present in cell types that regulate MN survival at the onset of the developmental cell death period. 
To determine whether the effects of GDNF on $\gamma$-MN survival are exerted in the conventional target-derived manner or in some other manner, we sought to correlate the time course of enhanced MN death and reduced motor spindle innervation in GDNF ligand/ receptor KOs, because it has been shown that the loss of MNs in these $\mathrm{KO}$ mice result from an increase in the death of MNs (Oppenheim et al., 2000). We first characterized the total number of dying lumbar MNs by staining with an antibody against HB9 (to determine the rostrocaudal extent of the lumbar LMC) and then labeling adjacent sections with an antibody against activated caspase- 3 and with the nuclear stain bisbenzimide (Fig. $7 A$ ). We found, similar to Oppenheim et al. (2000), that the number of dying cells at the earliest and latest stages of MN PCD (E12.5 and E16.5) was similar between $\operatorname{Ret}^{C F P /+}$ and Ret $^{\text {CFP/CFP }}$ mice (Table 3). From E13.5 to E15.5, when $\sim 80 \%$ of the neurons that die during this period are lost, Ret KOs exhibit a significantly higher number of dying MNs (Table 3). At the earliest stage that we could easily dissect individual muscles, E15.5, only hours after the induction of muscle spindles, we already detected an obvious reduction in the thickness of GFP-immunoreactive processes traveling alongside $\mathrm{PV}$-positive sensory axons to the muscle spindle (Fig. $7 B$ ). At E16.5, when differences in cell death between Ret KOs and Ret heterozygotes are no longer observed, we observed spindles almost completely devoid of fusimotor staining (Fig. 7B). Therefore, because $73 \%$ of the extra dying neurons in Ret KOs die before muscle spindles form (E12.5-E14.5) (Table 3), and because GFP-immunoreactive axons are already reduced in thickness just as they begin to terminate onto muscle spindles at E15.5 (Fig. $6 B)$, our data suggest that spindleinnervating $\gamma$-MNs are mostly reduced in GDNF ligand/receptor KOs by an early, target-independent mechanism. However, because $27 \%$ of these MNs are lost as $\gamma$-MNs begin to innervate their spindle targets (E15.5), it appears that target-derived GDNF signaling may further contribute to the reduction of MNs in these animals.

Our studies to this point indicate that the majority of hindlimb muscles in GDNF ligand/receptor KOs are normally innervated but that the number of innervated muscle spindles is reduced by target-dependent and target-independent mechanisms during development. However, because no clear marker for $\gamma$ - versus $\alpha$ (extrafusal-innervating)-MN cell bodies at P0 currently exists, it remained unclear whether the distal motor innervation deficits of hindlimb muscle spindles and the elevation of dying lumbar MNs were two independent measurements of the same effect or whether they were actually coincidental (i.e., that the increase in
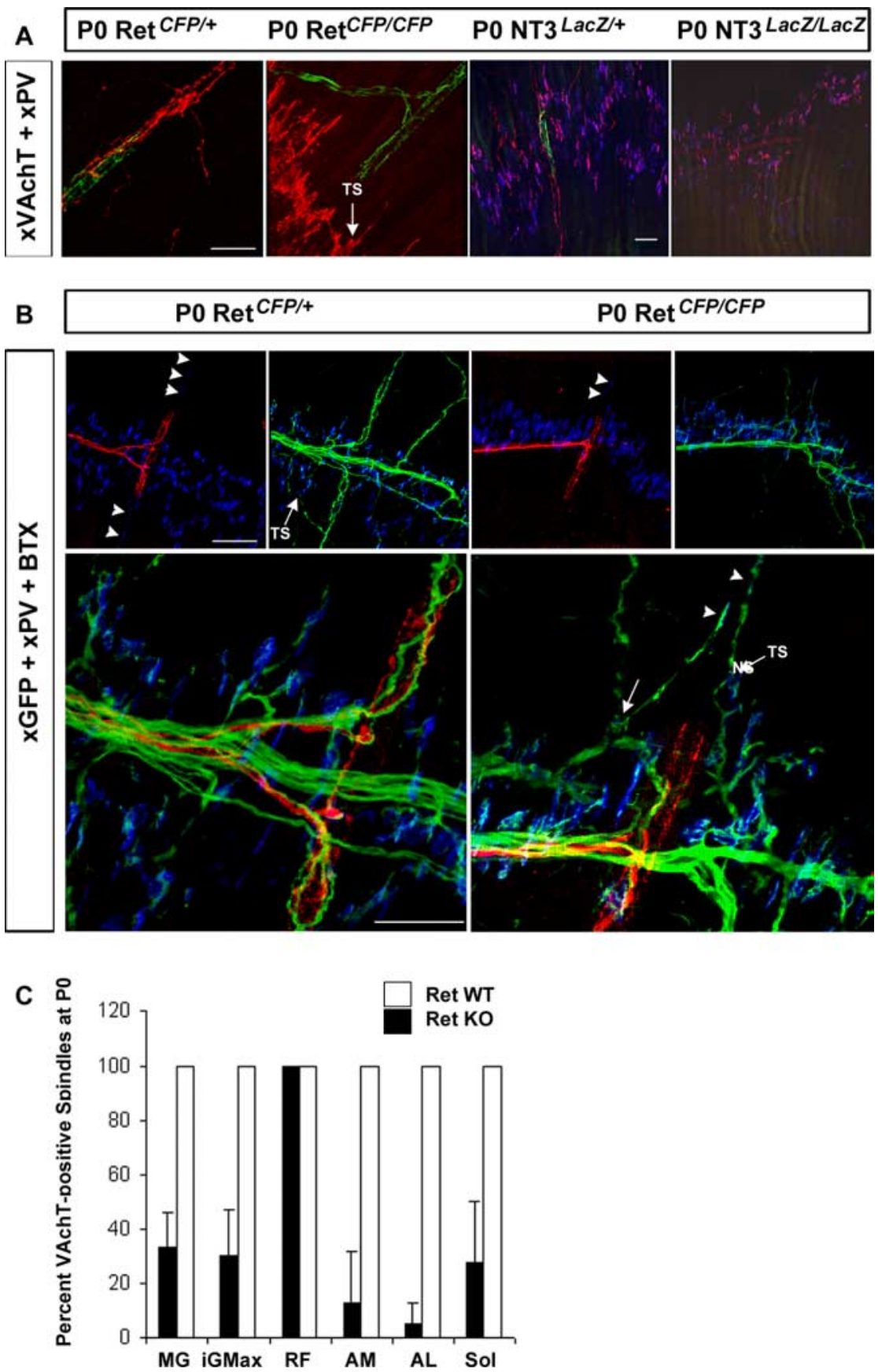

Figure 5. MNs fail to innervate muscle spindles in GDNF ligand/receptor KO mice in whole-mount preparations of iGMax. $\boldsymbol{A}$, Muscle spindlesidentified by sensoryneuron-derived PV immunoreactivity (green), fail to receive MN-derived cholinergic innervation (red) in PO Ret ${ }^{C F / C F P}$ mice (second panel), compared with PO Ret ${ }^{C F /+}$ mice, despite exhibiting normal motor innervation of the endplate band. A similar selective absence of fusimotor innervation is observed in PO NT3 KOs (fourth panel), which exhibit motor innervation (red) of extrafusal nAchRs only (blue). Scale bars: First and third panels, $50 \mu \mathrm{m}$. B. The equatorial and polar regions of muscle spindles receive annulospiral terminals from PV-positive sensory neurons (red) and efferent innervation from GFP-positive fusimotor MNs (green), respectively, in PO Ret ${ }^{C F P /+}$ (left three panels) but not PO Ret ${ }^{C F / C F P}$ mice (right three panels). Note the presence of nAChRs (blue) in both poles of the spindle (arrowheads) in Ret ${ }^{C F /+}$ mice. Ectopic GFP-labeled processes (arrows) (TS, terminal sprout; NS, nodal sprout) extending toward the spindle are sometimes associated with polarnAChRs in Ret KO mice at $\mathrm{PO}$, but are unable to maintain innervation postnatally (see text). Scale bars, $50 \mu \mathrm{m}$. C, The number of motor-innervated spindles is significantly reduced in most but not all muscles in $\mathrm{PO}$ Ret-null mutants. Whole muscles (iGMax; AL, adductor longus; SOL, soleus) or serial $40 \mu \mathrm{m}$ cross sections of entire muscles (MG, medial gastrocnemius; RF, rectus femoris; AM, adductor magnus) were stained with xVAchT and XPV antibodies to determine the total number of motor-innervated spindles.

cell death in Ret KOs actually affects only $\alpha$-MNs within multiple motor pools and that the $\gamma$-MNs that fail to innervate their spindle targets nevertheless do not die). To discriminate these possibilities, we sought to investigate the number of $\gamma$ - and $\alpha$-MNs in 


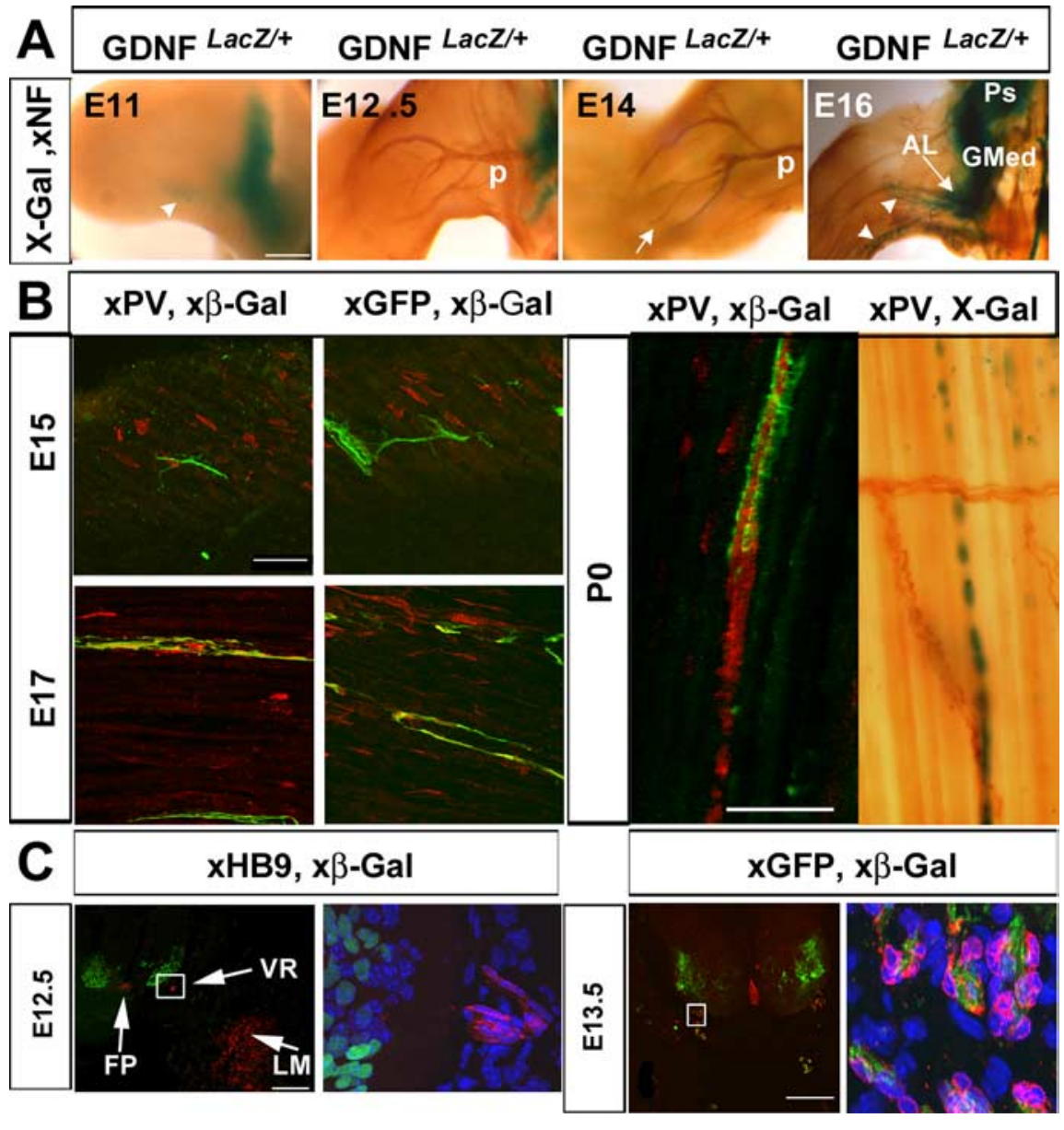

Figure 6. GDNF expression in the developing hindlimb is associated with MN defects. $\boldsymbol{A}$, Whole-mount X-gal staining of GDNF $^{\text {LaCZ/+ }}$ hindlimbs shows GDNF expression in the dorsal hindlimb bud (arrowhead, far left panel) just before peroneal motor axon extension into this region. In contrast, GDNF is not expressed in peroneal muscle targets at later ages when peroneal motor axons (p) have already begun to reach these targets (middle two panels), although X-gal is occasionally seen surrounding sensory nerves at this time (third panel, arrowhead). At later ages, GDNF can be detected in gluteal and iliopsoas muscles (GMed, gluteus medius; Ps, psoas; AL, adductor longus). Scale bar, $250 \mu \mathrm{m} . \boldsymbol{B}$, GDNF (x $\beta$-gal; red) is expressed by but not restricted to muscle fibers associated with PV-immunoreactive sensory nerve terminals (green; far left two panels) and GFP-positive motor terminals (green, near left two panels) at E15, the onset of fusimotor innervation, and at E17 in GDNF ${ }^{\mathrm{Lac} /+}{ }^{\text {, Ret }}{ }^{\mathrm{CFP} /+}$ mice. Note the increase in spindle-associated GDNF expression at 17 and $\mathrm{P} O$ (right panels). Scale bars: Left four panels, $50 \mu \mathrm{m}$; right two panels, $25 \mu \mathrm{m}$. C, GDNF (x $\beta$-gal; red) is expressed in floorplate (FP), limb mesenchyme (LM), and Schwann cells of the ventral root (VR) at E12.5, the beginning of the MN cell death period (left two panels) in GDNF ${ }^{\text {LacZ/+ }}$, Ret ${ }^{\mathrm{CF} /+}{ }^{+}$mice. Schwann cell nuclei (Hoechst; blue) expressing GDNF (red) closely appose GFP-positive motor axons (green) in E13.5 $\mathrm{GDNF}^{\mathrm{LaCZ} /+}$, Ret $^{\mathrm{CFP} /+}$ mice (right two panels). Scale bars, $200 \mu \mathrm{m}$.

GDNF ligand/receptor KOs in a more quantitative way, such as counting the number of large- and small-diameter myelinated axons in ventral roots and muscle-specific peripheral nerves. To obtain mice in which Ret was deleted that could live until the age of myelination, we crossed the conditional Ret and GFR $\alpha 1$ mice that we generated and described above to mice expressing Cre recombinase under the $\mathrm{MN}$-specific $\mathrm{HB} 9$ promoter (Arber et al., 1999). The progeny of these crosses, which were born in correct Mendelian ratios and are referred to here as HB9-Cre; Ret ${ }^{\text {flox/+ }}$, HB9-Cre; Ret flox/-, HB9-Cre; GFR $\alpha 1^{\text {flox/+ }}$, and HB9-Cre; GFR $\alpha 1^{\text {flox/- }}$ mice, express CFP or GFP in the floxed allele on Cre-mediated recombination (supplemental Fig. 1, available at www.jneurosci.org as supplemental material) (Uesaka et al., 2007). Therefore, we used both immunostaining against Ret/ GFR $\alpha 1$ to determine the number of MNs that failed to exhibit recombination as well as GFP immunostaining to determine the number of successfully recombined MNs in these animals (Fig.
8A) (data not shown). These analyses, together with the examination of the number of GFP-immunoreactive axons in the L4 ventral root, determined that the number of recombined lumbar MNs was $>90 \%$ (Fig. $8 B$ ) (data not shown).

We next examined the number of small- and large-diameter axons in 1- $\mu \mathrm{m}$ thick plastic-embedded sections of the lumbar ventral roots of adult (P42) MNspecific Ret and GFR $\alpha 1$ KOs. We observed a dramatic loss of small-diameter $(3 \mu \mathrm{m}$ or less) axons in the L4 ventral root of adult HB9-Cre; Ret flox/- and HB9-Cre; GFR $\alpha 1^{\text {flox/- }}$ mice, compared with their respective controls (Fig. 9A, Table 4). This effect was observed in all six lumbar ventral roots of HB9-Cre; Ret ${ }^{\text {flox/- }^{-}}$mice (Table 4). In contrast to this striking loss of small axons, the number of large-diameter axons was completely unaffected in the L1-L6 ventral roots of adult HB9-Cre; Ret $\mathrm{flox}^{\text {fl- }}$ mice (Table 4). Importantly, these data were generated from mice in which there was no peroneal nerve deficit, which we observed in approximately the same percentage of MN-specific Ret mutants as pan-Ret mutants (Table 2). In mice that did exhibit a severe peroneal deficit and that consequently exhibited the inversion phenotype described in Nestin-Cre; Ret $^{\text {flox/- }}$ mice by Kramer et al. (2006), the number of large-diameter axons was in fact reduced (Table 4), corroborating our findings of increased MN loss in this subtype of Ret KOs (Table 1). In addition to the reduction of small but not large motor axons in the proximal ventral root, we also observed a preferential reduction of small versus large axons in the distal medial gastrocnemius nerve (Fig. 9B, Table 4). We next measured the number of $\alpha 3 \mathrm{Na}^{+}, \mathrm{K}^{+}$ ATPase immunoreactive motor axons in the $\mathrm{L} 4$ ventral roots of $\mathrm{MN}$-specific Ret and GFR $\alpha 1$ KOs, because this has been used as a putative marker for $\gamma$-motor axons in the adult (Dobretsov et al., 2003; Buss et al., 2006). Similar to the marked reduction of small-myelinated axons, we detected far fewer $\alpha 3 \mathrm{Na}^{+}, \mathrm{K}^{+}$ATPase-immunoreactive axons in adult HB9Cre; Ret ${ }^{\text {flox/- }}$ and HB9-Cre GFR $\alpha 1^{\text {flox/- }}$ mice, versus respective controls (Fig. 9C). Furthermore, we observed a concordant reduction in the number of small, VAchT mRNA-labeled MNs in cross sections of the spinal cord of adult HB9-Cre; Ret ${ }^{\text {flox/- }}$ mice and compared with HB9-Cre; Ret ${ }^{\text {flox/+ }}$ mice (data not shown). Finally, we detected a similar total number of lumbar VAchT mRNA-positive MNs in P0.5 GDNF and NT-3 KO mice (Table 1), which fail to form spindles and therefore lack small-diameter fusimotor axons in the ventral root (Kucera et al., 1995a; Woolley et al., 1999). Together, these results support the idea that the trophic effects of GDNF on MNs, with the exception of the peroneal MNs, are restricted to spindle-innervating $\gamma$-MNs.

We next investigated the status of motor innervation of muscle spindles in adult $\mathrm{MN}$-specific Ret KOs, taking advantage of 
the fact that muscle spindles express calbindin in adult muscles (Chen et al., 2002) and that MNs express robust levels of Ret, and therefore CFP in our mice, postnatally (Zhang and Huang, 2006). In contrast to HB9-Cre; Ret ${ }^{\text {flox/+ }}$ mice, which expressed strong apposed GFP and $\alpha$-BTX staining at the polar regions of adult calbindin-labeled muscle spindles (Fig. 10A,C), HB9-Cre; Ret $^{\text {flox/- }}$ exhibited a complete lack of fusimotor innervation of many spindles (Fig. $10 B, D)$. In some cases, we observed GAP43 , GFP coimmunoreactive sprouts originating from axons proximal to a muscle spindle, which sometimes but not always were capable of inducing $\alpha$-BTX-labeled endplates (data not shown). In contrast to the large reduction of fusimotor nerve terminal staining, presynaptic terminals located on extrafusal nAChRs appeared mostly normal in $\mathrm{MN}$-specific Ret KOs, with the exception that GFP-positive terminal sprouts could occasionally be observed (Fig. 10E,F). These data suggest that the developmental effects of Ret deletion on fusimomotor innervation are maintained in adulthood and that successful compensatory reinnervation by remaining MNs fails to occur.

Because Ret expression persists in all MNs into adulthood and appears more highly expressed in small-diameter than large-diameter MNs (Jongen et al., 2007), we tested whether the requirement of GDNF for small-diameter $\gamma$-MNs was specific to development or extended postnatally. We crossed animals expressing a temporally inducible Cre under the ubiquitous $\beta$-actin promoter (CAGGCre-ER) (Hayashi and McMahon, 2002) to conditional Ret mice, treated with 4-OH-tamoxifen to induce Cre activity every day from P5 to P10 and waited nearly a year to examine fusimotor innervation (Fig. 11 $A$ ). These animals exhibited a recombination efficiency $>85 \%$, as measured by the number of NF-immunoreactive axons coexpressing GFP (Fig. $11 B$ ). We next examined the pattern of motor innervation of muscle spindles by tracking GFP expression in Ret-deficient motor axons of

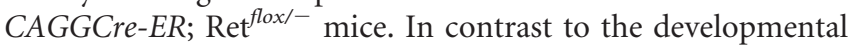
loss of Ret signaling within MNs, the early postnatal loss of Ret fails to affect the terminal staining of spindles by fusimotor axons (Fig. 11C) or the number of small myelinated axons in the L4 ventral root (Fig. 11D) (data not shown). These studies indicate that $\gamma$-MNs depend on Ret signaling only during the period of MN cell death.

Finally, because we observed a dichotomy between the types of MN deficit caused by GDNF ligand/receptor signaling according to the site of expression of GDNF (early or late-stage targets), we hypothesized that different signaling pathways might contribute to this dichotomy. For example, the peroneal nerve deficit appears to depend on early, target-independent GDNF, the sG-
Max/TFL/pPMaj deficit on target-derived GDNF, and the fusimotor deficit on both target-dependent and independent sources of GDNF. To address this issue, we generated mice lacking one or two of the tyrosines in Ret whose activation is associated with GDNF signaling, tyrosine-1015 and tyrosine-1062 (Hayashi et al., 2000; Coulpier et al., 2002; Jain et al., 2006) and examined their MN numbers and motor innervation. Whereas we failed to

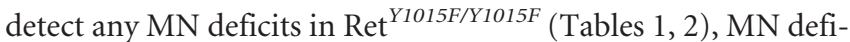
cits in Ret $^{\text {Y1062F/Y1062F }}$ mice mirrored those of Ret KO mice with the exception that $<10 \%$ of $\operatorname{Ret}^{Y 1062 F / Y 1062 F}$ mice exhibited peroneal nerve deficits (Tables 1, 2). Mice in which both the 1015 and 1062 tyrosine residues were mutated to phenylalanine appeared identical with those in which tyrosine 1062 alone was mutated, indicating that tyrosine-1015-mediated signaling is not 

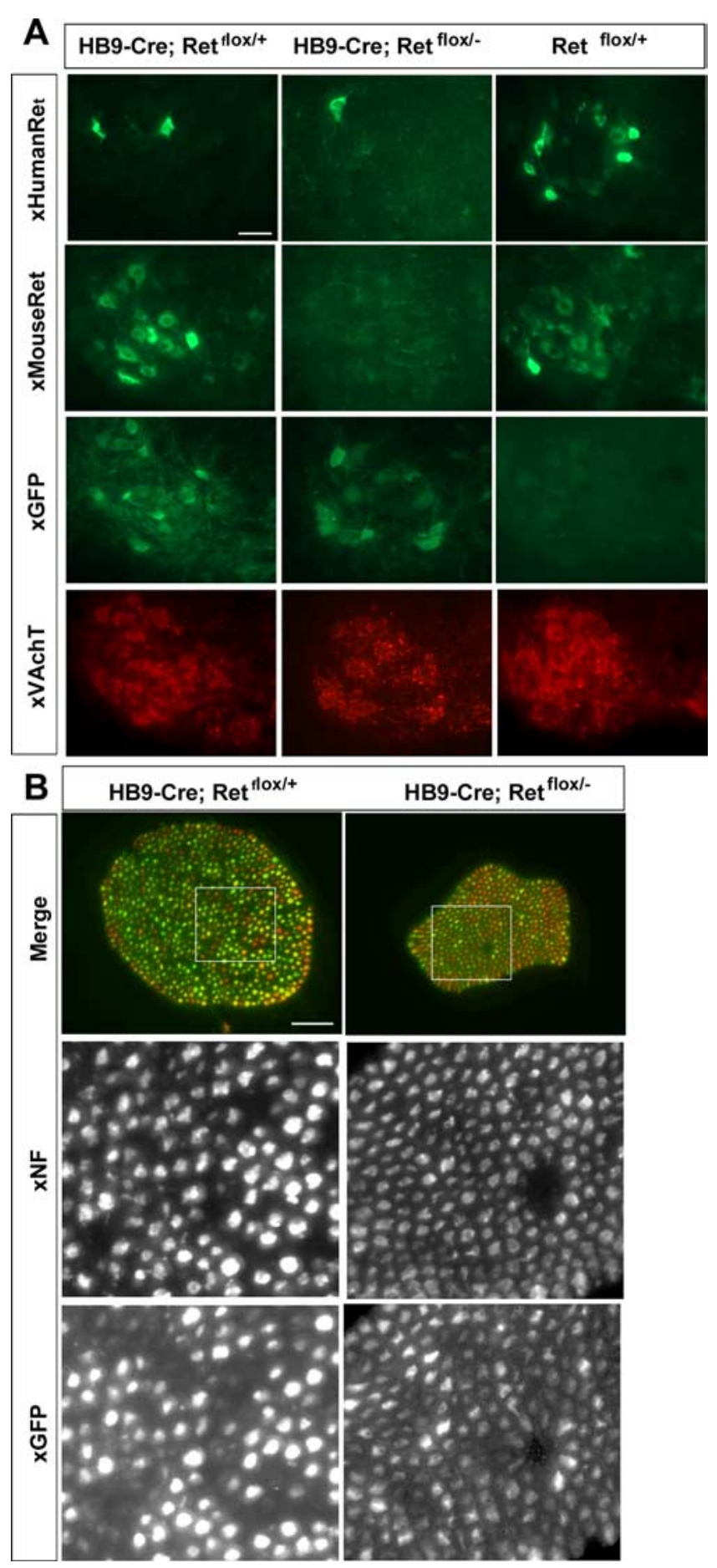

Figure 8. Conditional Ret mutant mice exhibit efficient recombination in MNs when crossed to HB9-Cre mice. A, Ret ${ }^{f l o x /+}$ mice, in which the floxed Ret allele includes a human Ret cDNA and multiple stop codons surrounded by loxP sites, followed by GFP, express human and mouse Ret in all MNs, but fail to express GFP (right column, top two panels). In contrast, when these mice are crossed to HB9-Cre mice, MNs lose expression of human Ret in most MNs, maintain expression of mouse Ret, and gain expression of GFP (left column, top three panels). HB9-Cre; Ret ${ }^{f l o x /-}$ mice, which contain the floxed allele and a null Ret allele, exhibit no mouse Ret, little human Ret, and robust GFP expression in VAchTpositive MNs. The number of MNs expressing human Ret was never $>1-2$ per section in HB9-Cre recombined mice. Scale bar, $100 \mu \mathrm{m}$. $\boldsymbol{B}$, The high degree of recombination was also observed in cross sections of the L4 VR of P42 MN-specific Ret mice by neurofilament (middle row) and GFP (bottom row) staining. Scale bar, $50 \mu \mathrm{m}$. required even when tyrosine-1062-mediated signaling is impaired. Together, these data suggest that tyrosine-1062-mediated Ret signaling is dispensable for peroneal MNs requiring only early GDNF signaling, but required for MNs that either partially (fusimotor) or totally (sGMax/TFL/pPMaj) depend on targetderived GDNF signaling.

\section{Discussion}

Neurotrophic effects of GDNF are restricted to one subtype of spinal MN

Using newly generated Ret and GFR $\alpha 1$ knock-in mice and a novel methodology to estimate the fusimotor innervation of muscle spindles, we have demonstrated that the neurotrophic effects of GDNF, one of the most potent survival factors for spinal MNs (Henderson et al., 1994; Oppenheim et al., 1995, 2000; Moore et al., 1996; Soler et al., 1999; Cacalano et al., 1998; Garcès et al., 2000; Whitehead et al., 2005; Buss et al., 2006; Brunet et al., 2007), are restricted to muscle spindleinnervating $(\gamma)$ fusimotor $\mathrm{MNs}$ and not extrafusal fiberinnervating skeletomotor $(\alpha)$ MNs. The dramatic, selective loss of small myelinated axons is observed in all six lumbar ventral roots of adult $\mathrm{MN}$-specific Ret/GFR $\alpha 1 \mathrm{KO}$ mice, in accord with a previous report that detected a decrease of spinal $\mathrm{MNs}$ at all rostrocaudal levels of the lumbar spinal cord (Oppenheim et al., 2000). Our results are also consistent with those of a previous study, which observed a loss of small- but not large-caliber myelinated motor axons in GDNF heterozygote mice (Whitehead et al., 2005). However, our studies are significantly different in the following four ways: (1) we have analyzed the absence of $\gamma$-MNs in GDNF ligand/receptor KOs by examination of MN cell body counts, small myelinated axon counts, and distally innervated spindles; (2) we have examined the neuromuscular system of postnatal animals that completely, rather than partially, lack GDNF signaling in MNs during development; (3) we examined all hindlimb muscles; and (4) we compared the development of fusimotor innervation with the time course of MN cell death and GDNF expression.

\section{Difference in the effects of GDNF on peroneal versus nonperoneal skeletomotor MNs}

Because Ret KOs completely lacking peroneal nerves exhibited an additional reduction of $\mathrm{MNs}$ approximately equal in amount to the number known to innervate the six peroneal muscles, GDNF might rescue from death these large MNs. However, this loss more likely reflects a tropic rather than a trophic effect of GDNF on peroneal MNs, because they survive well past the point when the peroneal deficit first emerges at E11.5, when GDNF is observed in the vicinity of their outgrowing axons (Kramer et al., 2006; this study). Furthermore, $\mathrm{MNs}$ that fail to form the dorsal peroneal nerve are misrouted into the ventral tibial nerve, indicating that they die well after the dorsoventral choice point (Kramer et al., 2006) and in agreement with the earliest time point at which more dying MNs are observed in KO embryos, E13.5. Therefore, we favor the idea that large-diameter peroneal MNs die indirectly as a result of early GDNF deprivation.

Whereas peroneal MNs encounter GDNF at this intermediate "choice point," MNs innervating the LD, CM, sGMax, TFL, and pPMaj muscles are exposed to GDNF at the final target (Haase et al., 2002; this study). Interestingly, mice in which the tyrosine1062 residue in Ret is mutated fail to exhibit peroneal projection errors, despite being otherwise indistinguishable from Ret-null 
mutants. This supports the idea that GDNF expression at the intermediate target signals through Ret-expressing peroneal MNs in an atypical Y1062 phosphorylation-independent manner and may provide insight into the mechanism underlying the cooperativity between Ret and Ephrin-A4 signaling in these MNs described by Kramer et al. (2006). The physiologically significant interaction between these two tyrosine kinases may extend beyond peroneal MNs (e.g., to fusimotor neurons), because a similar reduction in $\mathrm{MN}$ number extending across all lumbar segments was also observed in EphA4 KO mice (Helmbacher et al., 2000). Additional evidence supporting this hypothesis is provided by the finding that the gluteal, iliopsoas, and peroneal motor pools are all localized to lateral portions of the lumbar lateral motor column (Nicolopoulos-Stournaras and Iles, 1983), where EphA4 is preferentially expressed (Helmbacher et al., 2000). Together with the finding that EphA4 expression is downregulated in the lumbar spinal cord of GFR $\alpha 1$ KO mice (Garcès et al., 2000) (but see Kramer et al., 2006), these results suggest that lateral lumbar $\mathrm{MNs}$ require GDNF signaling in the dorsal limb bud to activate EphA4 expression, which acts to repulse these MNs from the ventral limb bud.

\section{Neurotrophic effects of GDNF on fusimotor neurons may be direct or indirect}

Based on their findings that GDNF is expressed robustly in developing muscle spindles, Whitehead et al. (2005) argued that GDNF is a final target-derived factor for fusimotor MN survival. However, because such a large proportion of the extra dying spinal MNs in Ret KOs occur before the onset of spindle formation, it seems probable that a significant number of prospective fusimotor $\mathrm{MNs}$ die as a result of spindle-independent sources of GDNF. This is in agreement with our observation that the numbers of spindleprojecting motor axons are reduced even before they reach the target. Because prospective skeletomotor and fusimotor neurons cannot be distinguished during this early developmental period, however, it remains unclear whether the subsequent absence of fusimotor innervation reflects a deficiency in neurotrophic signaling to newly differentiated but indistinct $\gamma$-MNs, or a deficit in some other aspect of $\gamma-\mathrm{MN}$ development. For example, early GDNF may be required for the differentiation of $\gamma$-MNs from a common $\alpha$, $\gamma$ precursor population, resulting in a greater number of $\alpha$-MNs, the excess of which are eliminated by GDNF-independent mechanisms at extrafusal junctions. Alternatively, early GDNF may be required for the competence of newly differentiated $\gamma$-MNs to
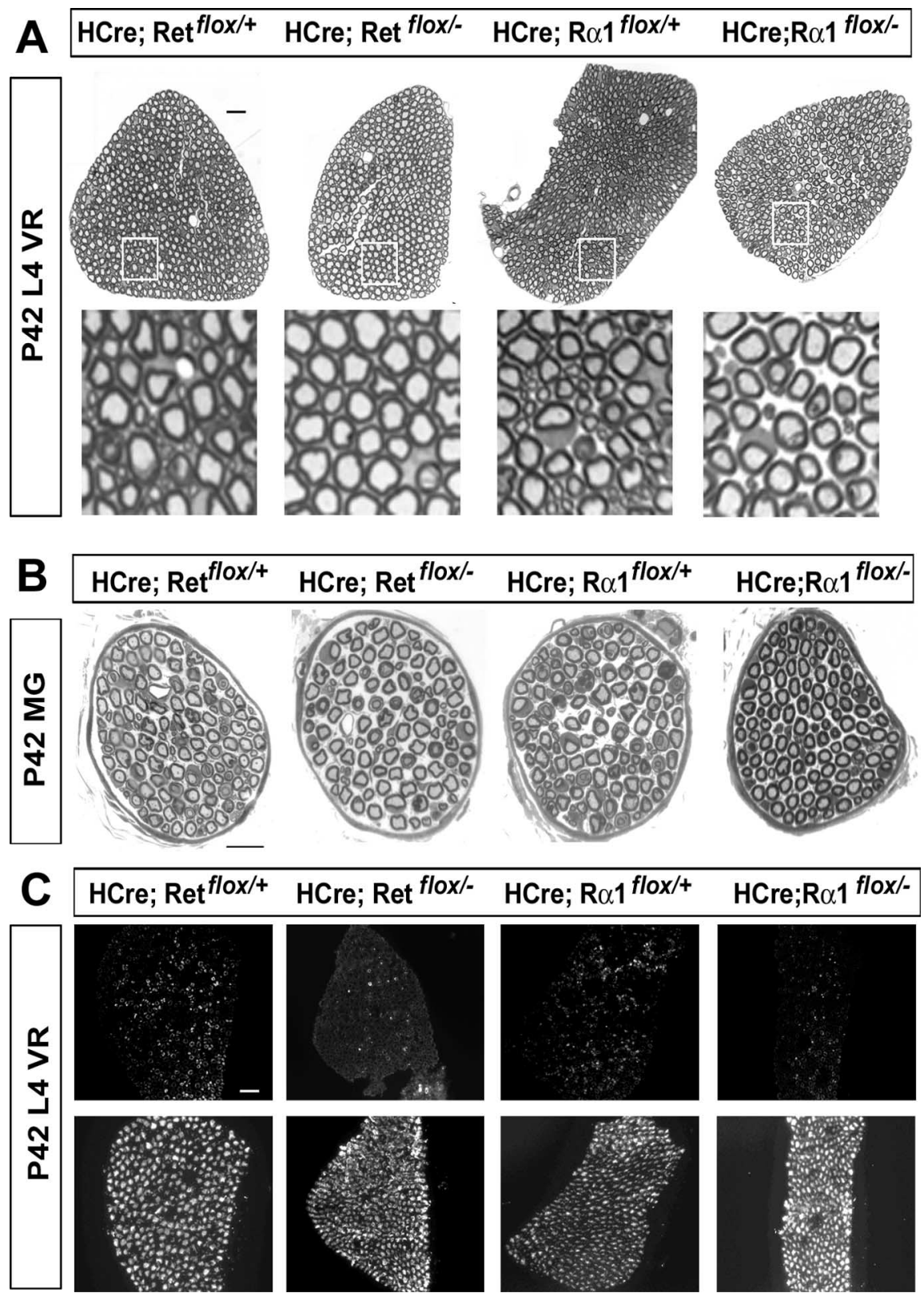

Figure 9. Conditional deletion of Ret or GFR $\alpha 1$ in MNs results in a dramatic decrease in the number of small myelinated motor axons. $\boldsymbol{A}, \boldsymbol{B}$, One-micrometer-thick plastic sections of the $L 4 \mathrm{VR}(\boldsymbol{A})$ and the medial gastrocnemius nerve $(\boldsymbol{B})$ of $\mathrm{P} 42 \mathrm{HB} 9-\mathrm{Cre}$; $\operatorname{Ret}^{\text {flox/- }}$ (P42 HCre; Ret ${ }^{\text {flox/- }}$ ) and P42 HB9-Cre; GFR $\alpha 1^{\text {flox/- }}$ (P42 HCre; R1 ${ }^{\text {flox/- }}$ ) mice (second, fourth panels) show a striking reduction of small myelinated axons, compared with control. $C$, Cross sections of the L4 VR show a reduction in the number xNF-labeled axons (bottom panels) that express $\alpha 3 \mathrm{Na}^{+}, \mathrm{K}^{+}$ATPase (top panels), a putative marker of fusimotor axons in MN-specific Ret and GFR $\alpha 1 \mathrm{KO}$, relative to control. Scale bars: $\boldsymbol{A}-\boldsymbol{C}, 20 \mu \mathrm{m}$.

respond to intrafusal fiber-derived trophic factors (including GDNF itself). Interestingly, a recent report provided evidence that adult fusimotor MNs express higher levels of Ret than skeletomotor MNs (Jongen et al., 2007). Similarly, developing peroneal MNs, which require GDNF, express higher levels of Ret than GDNF-resistant tibial MNs (Kramer et al., 2006). Thus, embryonic MNs destined to innervate spindles may require early GDNF signaling for the upregulation of Ret, which is required for the response to subsequent GDNF trophic support present at the muscle spindle. Identification of specific markers distinguishing prospective $\alpha$ - from $\gamma$-MNs may elucidate the mechanisms by which GDNF regulates fusimotor innervation. 
Table 4. Numbers of total, small, and large myelinated axons in P42 mice deficient for Ret or GFR 1 in MNs

\begin{tabular}{|c|c|c|c|c|c|c|c|c|}
\hline & L1 & L2 & L3 & $\mathrm{L}^{\mathrm{g}}$ & $44^{b}$ & $\mathrm{~L} 5$ & L6 & MG \\
\hline \multicolumn{9}{|l|}{ Total myelinated axons } \\
\hline HB9-Cre;Ret ${ }^{f l o x /+}$ & $341 \pm 25(n=3)$ & $538 \pm 13$ & $784 \pm 106$ & $947 \pm 68$ & NA & $547 \pm 59$ & $218 \pm 76$ & $131 \pm 11$ \\
\hline HB9-Cre;Ret ${ }^{f l o x /}-$ & $263 \pm 40(n=3)$ & $414 \pm 69$ & $501 \pm 45^{* *}$ & $799 \pm 17$ & $590 \pm 54^{* *}$ & $404 \pm 53$ & $163 \pm 40$ & $96 \pm 10^{* *}$ \\
\hline HB9-Cre;GFR $\alpha 1^{f l o x /+}$ & ND & ND & ND & $943 \pm 6$ & NA & ND & ND & $130 \pm 5$ \\
\hline HB9-Cre;GFR $\alpha 1^{f l o x /-}$ & ND & ND & ND & $789 \pm 58^{*}$ & $594 \pm 58^{*}$ & ND & ND & $99 \pm 4^{* * *}$ \\
\hline \multicolumn{9}{|l|}{ Small myelinated axons } \\
\hline HB9-Cre;Ret ${ }^{\text {flox/+ }}$ & $155 \pm 11(n=3)$ & $207 \pm 29$ & $272 \pm 29$ & $301 \pm 4$ & NA & $201 \pm 27$ & $92 \pm 42$ & $35 \pm 6$ \\
\hline HB9-Cre;Ret ${ }^{f l x /}-$ & $37 \pm 20^{*}(n=3)$ & $41 \pm 23^{*}$ & $21 \pm 4^{* *}$ & $51 \pm 19^{* * *}$ & ND & $48 \pm 16^{*}$ & $17 \pm 12$ & $14 \pm 5^{* * *}$ \\
\hline HB9-Cre;GFR $\alpha 1^{f l o x /+}$ & ND & ND & ND & $258 \pm 24$ & ND & ND & ND & $31 \pm 2$ \\
\hline HB9-Cre;GFR $\alpha 1^{\text {flox/- }}$ & ND & ND & ND & $107 \pm 9^{*}$ & ND & ND & ND & $13 \pm 2^{* *}$ \\
\hline \multicolumn{9}{|l|}{ Large myelinated axons } \\
\hline HB9-Cre;Ret ${ }^{f l o x /+}$ & $186 \pm 19(n=3)$ & $331 \pm 31$ & $512 \pm 84$ & $643 \pm 63$ & NA & $346 \pm 54$ & $127 \pm 36$ & $97 \pm 8$ \\
\hline HB9-Cre;Ret ${ }^{f l o x /}-$ & $226 \pm 21(n=3)$ & $372 \pm 71$ & $483 \pm 42$ & $762 \pm 21$ & $509 \pm 68^{5}$ & $356 \pm 37$ & $146 \pm 52$ & $82 \pm 9^{*}$ \\
\hline HB9-Cre;GFR $\alpha 1^{f l o x /+}$ & ND & ND & ND & $685 \pm 18$ & ND & ND & ND & $98 \pm 5$ \\
\hline HB9-Cre;GFR $\alpha 1^{f l o x /-}$ & ND & ND & ND & $682 \pm 87$ & ND & ND & ND & $86 \pm 6^{*}$ \\
\hline
\end{tabular}

$N A$, Not applicable; ND, not determined; $g$, good; $b$, bad.

${ }^{*} p<0.05 ;{ }^{* *} p<0.01 ;{ }^{* * *} p<0.005 ;{ }^{\$} p<0.05$.

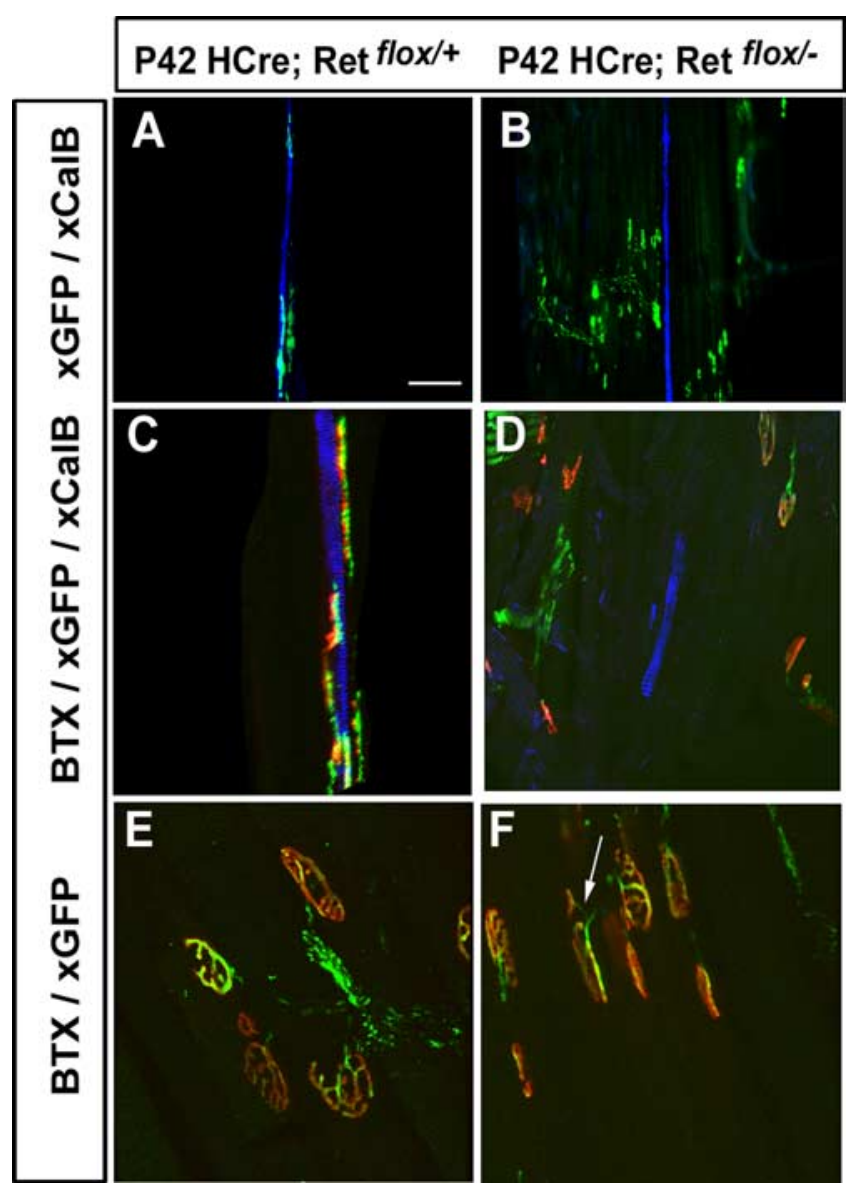

Figure 10. Muscle spindles remain devoid of motor innervation in adult MN-specific Ret KO mice. $\boldsymbol{A}-\boldsymbol{D}$, Low-power $(\boldsymbol{A}, \boldsymbol{B})$ and high-power $(\boldsymbol{C}, \boldsymbol{D})$ images of different spindles stained with antibodies against calbindin (Ca|B) (blue) show the elaboration of fusimotor terminals and apposing $n A C h R s$, stained with GFP antibodies (green) and Cy3- $\alpha$ BTX (red), in P42 HB9-Cre; Ret ${ }^{\text {flox/+ }}$ mice (P42 HCre; $\left.\operatorname{Ret}^{\text {flox/+ }}\right)\left(A, C\right.$. In contrast, spindles in HB9-Cre; Ret ${ }^{f l o x} /-$ mice fail to exhibit such fusimotor staining $(\boldsymbol{B}, \boldsymbol{D}) . \boldsymbol{E}, \boldsymbol{F}$, Despite showing these deficits, skeletomotor innervation (xGFP; green) of extrafusal $\mathrm{nAChRs}$ (Cy3- $\alpha \mathrm{BTX}$; red) is intact in MN-specific Ret KOs, despite occasionally showing GFP-labeled terminal sprouts ( $\boldsymbol{F}$, arrow). Scale bar: $\boldsymbol{A}, \boldsymbol{B}, 100 \mu \mathrm{m} ; \boldsymbol{C}-\boldsymbol{F}, 50 \mu \mathrm{m}$.

Fusimotor MNs depend on GDNF only during the period of developmental cell death

To determine whether or not the effects of GDNF deprivation were temporally specific, we deleted Ret both embryonically in
MNs and postnatally in all tissues. Using GFP as a marker for fusimotor neurons in Ret-deleted neurons, we could easily determine that the failure of $\gamma$-MNs to innervate their targets in panRet $\mathrm{KO}$ mice was maintained in adult MN-specific Ret KO mice, but that elimination of Ret postnatally had no effect. These data suggest that fusimotor MNs require GDNF only transiently. However, fusimotor MNs do require the continued presence of other spindle-associated trophic factors after birth, because mice in which the muscle spindle degenerates early postnatally exhibit a retraction of fusimotor innervation and reduction of small myelinated axons (EGR3 mutants) (Tourtellotte and Milbrandt, 1998; Tourtellotte et al., 2001). Nevertheless, the failure to observe the postnatal motor innervation of muscle spindles by remaining $\alpha$ - or $\gamma$-MNs in developmental MN-specific Ret KOs indicates that these MNs are unable to respond to any such factor.

We never observed any postnatal loss of MNs or motor axons in adult MN-specific Ret/GFR $\alpha 1$ KOs (compare the total number of L1-L6 motor axons in Table 4 with the number of MNs in Table 1), suggesting that GDNF is not required postnatally for the survival of $\alpha$-MNs. The relatively high levels of Ret that are maintained throughout adulthood in MNs (Zhang and Huang, 2006) may therefore reflect the well established role for GDNF in MN function after injury (Li et al., 1995; Oppenheim et al., 1995; Soler et al., 1999; Sun and Oppenheim, 2003; Zhao et al., 2004). Alternatively, GDNF may regulate the physiological function of developing or adult MNs (Wang et al., 2001; Martin-Caraballo and Dryer, 2002). Finally, MN-specific Ret KOs should provide a unique tool to study the function of $\gamma$-MNs, which modulate muscle spindle sensitivity to stretch and firing rate (Matthews, 1981) and therefore regulate proprioceptive function during a variety of behavioral tasks such as locomotion (Murphy and Martin, 1993).

The ability of GDNF to delay life span in mouse models of familial amyotrophic lateral sclerosis (fALS) (Manabe et al., 2002; Wang et al., 2002; Kaspar et al., 2003; Li et al., 2007) (but see Guillot et al., 2004) suggests that MNs may require this factor during adulthood. However, we have not noticed any obvious signs of MN degeneration in young ( $<5$ months) adult Ret KO mice (T. W. Gould and H. Enomoto, unpublished observations), indicating that the postnatal absence of GDNF is insufficient to cause MN disease. These findings provide a strong note of caution vis-à-vis the therapeutic use of GDNF in ALS or other MN diseases. Finally, because it has been hypothesized that $\gamma$-MNs are 
A

start
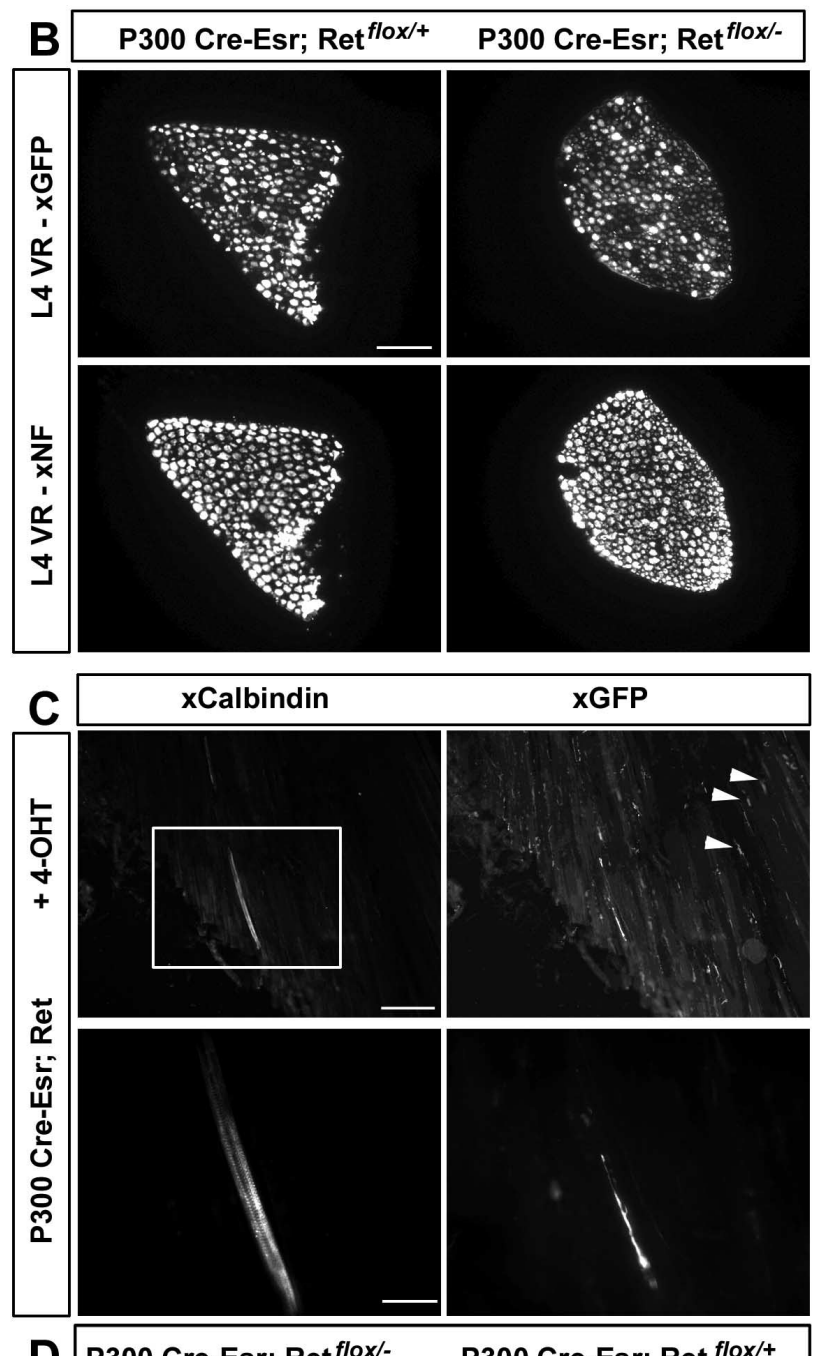

D P300 Cre-Esr; Ret $^{\text {flox/- }}$

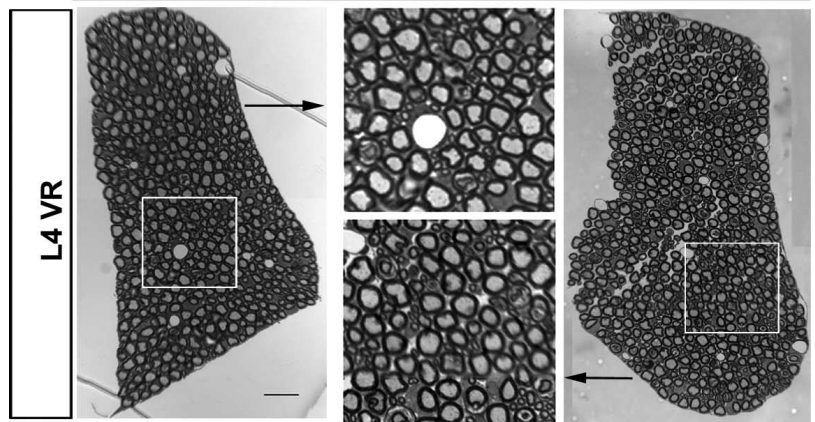

Figure 11. Postnatal deletion of Ret fails to disrupt fusimotor innervation. $A$, Ret was deleted in a pan-specific manner at $\mathrm{P} 5$ by addition of 4-OH-tamoxifen (T) daily from P5 to P10 to $\beta$-actin-Cre-Esr; Ret $^{f l o x /}$ - mice, and muscle spindles were analyzed at P300. $\boldsymbol{B}$, Most NF-immunoreactive axons (bottom panels) express GFP (top panels) at P300 after early treatment with 4-OHT in $\beta$-actin-Cre-Esr; Ret $^{f l o x /+}$ and $\beta$-actin-Cre-Esr; Ret ${ }^{f f o \gamma-}$ mice. Scale bar, $50 \mu \mathrm{m}$. C, Low- and high-power images of the same spindles (top, bottom panels) stained with calbindin antibodies (left panels) show intact fusimotor innervation by GFP immunoreactivity (right panels) in P300 $\beta$-actin-Cre-Esr; Ret ${ }^{f l o x}-{ }^{-}$mice treated with 4-0HT from P5 to P10. Note GFP-immunoreactive muscle cells (arrowheads, top right panel).Scale bars: Top, $200 \mu \mathrm{m}$; bottom, $50 \mu \mathrm{m}$. D, Postnatal Ret deletion fails to alter the number of small-diameter motor axons of the L4 VR (left panel, inset top middle), compared with control (right panel, inset bottom panel). Scale bar, $20 \mu \mathrm{m}$. selectively protected from neurodegeneration in ALS, based on the retention of small-diameter motor axons at late stages of disease (Kawamura et al., 1977), it will be worth examining the ventral roots of fALS mice crossed to MN-specific Ret or GFR $\alpha 1$ KOs, which lack $>80 \%$ of small-caliber axons.

\section{References}

Arber S, Han B, Mendelsohn M, Smith M, Jessell TM, Sockanathan S (1999) Requirement for the homeobox gene $\mathrm{Hb} 9$ in the consolidation of motor neuron identity. Neuron 23:659-674.

Arce V, Pollock RA, Philippe J-M, Pennica D, Henderson CE, deLapeyriére D (1998) Synergistic effects of Schwann- and muscle-derived factors on motoneuron survival involved GDNF and cardiotrophin-1 (CT-1). J Neurosci 18:1440-1448.

Baudet C, Mikaels A, Westphal H, Johansen J, Johansen TE, Ernfors P (2000) Positive and negative interactions of GDNF, NTN and ART in developing sensory neuron subpopulations, and their collaboration with neurotrophins. Development 127:4335-4344.

Biscoe TJ, Nickels SM, Stirling CA (1982) Numbers and sizes of nerve fibres in mouse spinal roots. Q J Exp Physiol 67:473-494.

Brunet N, Tarabal O, Portero-Otin M, Oppenheim RW, Esquerda JE, Caldero J (2007) Survival and death of mature avian motoneurons in organotypic slice culture: trophic requirements for survival and different types of degeneration. J Comp Neurol 501:669-690.

Buss RR, Gould TW, Ma J, Vinsant S, Prevette D, Winseck A, Toops KA, Hammarback JA, Smith TL, Oppenheim RW (2006) Neuromuscular development in the absence of programmed cell death: phenotypic alteration of motoneurons and muscle. J Neurosci 26:13413-13427.

Cacalano G, Fariñas I, Want L-C, Hagler K, Forgie A, Moore M, Armanini M, Phillips H, Ryan AM, Reichardt LF, Hynes M, Davies A, Rosenthal A (1998) GFR $\alpha 1$ is an essential receptor component for GDNF in the developing nervous system and kidney. Neuron 21:53-62.

Chen HH, Tourtellotte WG, Frank E (2002) Muscle spindle-derived neurotrophin 3 regulates synaptic connectivity between muscle sensory and motor neurons. J Neurosci 22:3512-3519.

Coulpier M, Anders J, Ibanez CF (2002) Coordinated activation of autophosphorylation sites in the RET receptor tyrosine kinase: importance of tyrosine 1062 for GDNF mediated neuronal differentiation and survival. J Biol Chem 277:1991-1999.

Dobretsov M, Hastings SL, Sims TJ, Stimers JR, Romanovsky D (2003) Stretch receptor-associated expression of alpha 3 isoform of the $\mathrm{Na}^{+}$ $\mathrm{K}^{+}$-ATPase in rat peripheral nervous system. Neuroscience 116:1069-1080.

Enomoto H, Araki T, Jackman A, Heuckeroth RO, Snider WD, Johnson Jr EM, Milbrandt J (1998) GFR $\alpha 1$-deficient mice have deficits in the enteric nervous system and kidneys. Neuron 21:317-324.

Enomoto H, Crawford PA, Gorodinsky A, Heuckeroth RO, Johnson Jr EM, Milbrandt J (2001) RET signaling is essential for migration, axonal growth and axon guidance of developing sympathetic neurons. Development 128:3963-3974.

Enomoto H, Hughes I, Golden J, Baloh RH, Yonemura S, Heuckeroth RO, Johnson Jr EM, Milbrandt J (2004) GFRalphal expression in cells lacking RET is dispensable for organogenesis and nerve regeneration. Neuron 44:623-636.

Ernfors P, Lee KF, Kucera J, Jaenisch R (1994) Lack of neurotrophin-3 leads to deficiencies in the peripheral nervous system and loss of limb proprioceptive afferents. Cell 77:503-512.

Farinas I, Yoshida CK, Backus C, Reichardt LF (1996) Lack of neurotrophin-3 results in death of spinal sensory neurons and premature differentiation of their precursors 17:1065-1078.

Garcès A, Haase G, Airaksinen MS, Livet J, Filippi P, deLapeyriere O (2000) GFR $\alpha 1$ is required for development of distinct subpopulations of motoneuron. J Neurosci 20:4992-5000.

Gerrits PO, Boers J, Holstege G (1997) The lumbar cord location of the motoneurons innervating psoas and iliacus muscles: a single and double labeling study in the female Syrian golden hamster. Neurosci Lett 237:125-128.

Gould TW, Oppenheim RW (2004) The function of neurotrophic factor receptors expressed by the developing adductor motor pool in vivo. J Neurosci 24:4668-4682.

Gould TW, Oppenheim RW (2006) Neuronal death and rescue: neurotrophic factors and anti-apoptotic mechanisms. In: Textbook of neural re- 
pair and neurorehabilitation (Selzer M, Clarke S, Cohen L, Duncan P, Gage F, eds), pp 271-292. Cambridge, UK: Cambridge UP.

Gould TW, Buss RR, Vinsant S, Prevette D, Sun W, Knudson CM, Milligan CE, Oppenheim RW (2006) Complete dissociation of motor neuron death from motor dysfunction by Bax deletion in a mouse model of ALS. J Neurosci 26:8774-8786.

Guillot S, Azzouz M, Déglon N, Zurn A, Aebischer P (2004) Local GDNF expression mediated by lentiviral vector protects facial nerve motoneurons but not spinal motoneurons in SOD1(G93A) transgenic mice. Neurobiol Dis 16:139-149.

Haase G, Dessaud E, Garces A, de Bovis B, Birling M, Filippi P, Schmalbruch $\mathrm{H}$, Arber S, deLapeyrière O (2002) GDNF acts through PEA3 to regulate cell body positioning and muscle innervation of specific motor neuron pools. Neuron 35:893-905.

Hayashi H, Ichihara M, Iwashita T, Murakami H, Shimono Y, Kawai K, Kurokawa K, Murakumo Y, Imai T, Funahashi H, Nakao A, Takahashi M (2000) Characterization of intracellular signals via tyrosine 1062 in RET activated by glial cell line-derived neurotrophic factor. Oncogene 19:4469-4475.

Hayashi SY, McMahon AP (2002) Efficient recombination in diverse tissues by a tamoxifen-inducible form of Cre: a tool for temporally regulated gene activation/inactivation in the mouse. Dev Biol 244:305-318.

Hebel R, Stromberg MW (1986) Anatomy and embryology of the laboratory rat. Wörthsee, Germany: BioMed Verlag.

Helmbacher F, Schneider-Maunoury S, Topilko P, Tiret L, Charnay P (2000) Targeting of the EphA4 tyrosine kinase receptor affects dorsal/ventral pathfinding of limb motor axons. Development 127:3313-3324.

Henderson CE (1996) Role of neurotrophic factors in neuronal development. Curr Opin Neurobiol 6:64-70.

Henderson CE, Phillips HS, Pollock RA, Davies AM, Lemeulle C, Armanini M, Simmons L, Moffet B, Vandlen RA, Simpson LC, Moffet B, Vandlen RA, Koliatsor VE, Rosenthal A (1994) GDNF: a potent survival factor for motoneurons present in peripheral nerve and muscle. Science 266:1062-1064.

Holtmann B, Wiese S, Samsam M, Grohmann K, Pennica D, Martini R, Sendtner M (2005) Triple knock-out of CNTF, LIF, and CT-1 defines cooperative and distinct roles of these neurotrophic factors for motoneuron maintenance and function. J Neurosci 25:1778-1787.

Jain S, Encinas M, Johnson Jr EM, Milbrandt J (2006) Critical and distinct roles for key RET tyrosine docking sites in renal development. Genes Dev 20:321-333.

Jongen JL, Jaarsma D, Hossaini M, Natarajan D, Haasdijk ED, Holstege JC (2007) Distribution of RET immunoreactivity in the rodent spinal cord and changes after nerve injury. J Comp Neurol 500:1136-1153.

Kaspar BK, Llado J, Sherkat N, Rothstein JD, Gage FH (2003) Retrograde viral delivery of IGF-1 prolongs survival in a mouse ALS model. Science 301:839-842.

Kawamura Y, Okazaki H, O’Brien PC, Dych PJ (1977) Lumbar motoneurons of man: I) number and diameter histogram of alpha and gamma axons of ventral root. J Neuropathol Exp Neurol 36:853-860.

Korsching S (1993) The neurotrophic factor concept: a re-examination. J Neurosci 13:2739-2748.

Kramer ER, Knott L, Su F, Dessaud E, Krull CE, Helmbacher F, Klein R (2006) Cooperation between GDNF/Ret and ephrinA/EphA4 signals for motor-axon pathway selection in the limb. Neuron 50:35-47.

Kucera J, Ernfors P, Walro J, Jaenisch R (1995a) Reduction in the number of spinal motor neurons in neurotrophin-3-deficient mice. Neuroscience 69:321-330.

Kucera J, Fan G, Jaenisch R, Linnarsson S, Ernfors P (1995b) Dependence of developing group Ia afferents on neurotrophin-3. J Comp Neurol 363:307-320.

Li L, Wu W, Lin LF, Lei M, Oppenheim RW, Houenou LJ (1995) Rescue of adult mouse motoneurons from injury-induced cell death by glial cell line-derived neurotrophic factor. Proc Natl Acad Sci USA 92:9771-9775.

Li W, Brakefield D, Pan Y, Hunter D, Myckatyn TM, Parsadanian A (2007) Muscle-derived but not centrally derived transgene GDNF is neuroprotective in G93A-SOD1 mouse model of ALS. Exp Neurol 203:457-471.

Livet J, Sigrist M, Stroebel S, De Paola V, Price SR, Henderson CE, Jessell TM, Arber S (2002) ETS gene Pea3 controls the central position and terminal arborization of specific motor neuron pools. Neuron 35:877-892.

Manabe Y, Nagano I, Gazi MS, Murakami T, Shiote M, Shoji M, Kitagawa H, Setoguchi Y, Abe K (2002) Adenovirus-mediated gene transfer of glial cell line-derived neurotrophic factor prevents motor neuron loss of transgenic model mice for amyotrophic lateral sclerosis. Apoptosis 7:329-334.

Martin-Caraballo M, Dryer SE (2002) Glial cell line-derived neurotrophic factor and target-dependent regulation of large-conductance $\mathrm{K}(\mathrm{Ca})$ channels in developing chick lumbar motoneurons. J Neurosci 22:10201-10208.

Matthews PB (1981) Evolving views on the internal operation and functional role of the muscle spindle. J Physiol (Lond) 320:1-30.

Meyers EN, Lewandowski M, Martin GM (1998) An Fgf8 mutant allelic series generated by Cre- and Flp-mediated recombination. Nat Genet 18:136-141.

Moore MW, Klein RD, Fariñas, Sauer H, Armanini M, Phillips H, Reichardt LF, Ryan AM, Carver-Moore K, Rosenthal A (1996) Renal and neuronal abnormalities in mice lacking GDNF. Nature 382:76-79.

Murphy PR, Martin HA (1993) Fusimotor discharge patterns during rhythmic movements. Trends Neurosci 16:273-278.

Naveilhan P, ElShamy WM, Ernfors P (1997) Differential regulation of mRNAs for GDNF and its receptors Ret and GDNFR alpha after sciatic nerve lesion in the mouse. Eur J Neurosci 9:1450-1460.

Nguyen QT, Parsadanian AS, Snider WD, Lichtman JW (1998) Hyperinnervation of neuromuscular junctions caused by GDNF overexpression in muscle. Science 279:1725-1729.

Nicolopoulos-Stournaras S, Iles JF (1983) Motor neuron columns in the lumbar spinal cord of the rat. J Comp Neurol 217:75-85.

Oppenheim RW, Houenou L, Pincon-Raymond M, Powell JA, Rieger F, Standish LJ (1986) The development of motoneurons in the embryonic spinal cord of the mouse mutant, muscular dysgenesis (mdg/mdg): survival, morphology, and biochemical differentiation. Dev Biol 114:426-436

Oppenheim RW, Houenou LJ, Johnson JE, Lin LF, Li L, Lo AC, Newsome AL, Prevette DM, Wang S (1995) Developing motor neurons rescued from programmed and axotomy-induced cell death by GDNF. Nature 373:344-346.

Oppenheim RW, Houenou LJ, Parsadanian AS, Prevette D, Snider WD, Shen L (2000) Glial cell line-derived neurotrophic factor and developing mammalian motoneurons: regulation of programmed cell death among motoneuron subtypes. J Neurosci 20:5001-5011.

Oppenheim RW, Wiese S, Prevette D, Armanini M, Wang S, Houenou LJ, Holtmann B, Gotz R, Pennica D, Sendtner M (2001) Cardiotrophin-1, a muscle-derived cytokine, is required for the survival of subpopulations of developing motoneurons. J Neurosci 21:1283-1291.

Price SR, Briscoe J (2004) The generation and diversification of spinal motor neurons: signals and responses. Mech Dev 121:1103-1115.

Purves D (1986) The trophic theory of neuronal connections. Trends Neurosci 9:486-489.

Rodriguez CI, Buchholz F, Galloway J, Sequerra R, Kasper J, Ayala R, Stewart AF, Dymecki SM (2000) High-efficiency deleter mice show that FLPe is an alternative to Cre-loxP. Nat Genet 25:139-140.

Sánchez MP, Silos-Santiago I, Frisén J, He B, Lira SA, Barbacid M (1996) Renal agenesis and the absence of enteric neurons in mice lacking GDNF. Nature 382:70-73.

Santini M, Ibata Y (1971) The fine structure of thin unmyelinated axons within muscle spindles. Brain Res 33:289-302.

Soler RM, Dolcet X, Encinas M, Eges J, Bayascas JR, Comella JX (1999) Receptors of the glial cell line derived neurotrophic factor family of trophic factors signal cell survival through the phosphatidylinositol 3-kinase pathway in spinal cord motoneurons. J Neurosci 19:9160-9169.

Sun W, Oppenheim RW (2003) Response of motoneurons to neonatal axotomy in Bax-knockout mice. Mol Cell Neurosci 24:875-886.

Tessarollo L, Vogel KS, Palko ME, Reid SW, Parada LF (1994) Targeted mutation in the neurotrophin-3 gene results in loss of muscle sensory neurons. Proc Natl Acad Sci USA 91:11844-11848.

Tourtellotte WG, Milbrandt J (1998) Sensory ataxia and muscle spindle agenesis in mice lacking the transcription factor Egr3. Nat Genet 20:87-91.

Tourtellotte WG, Keller-Peck C, Milbrandt J, Kucera J (2001) The transcription factor Egr3 modulates sensory axon-myotube interactions during muscle spindle morphogenesis. Dev Biol 232:388-399.

Trupp M, Belluardo N, Funakoshi H, Ibáñez CF (1997) Complementary and overlapping expression of glial cell line-derived neurotrophic factor (GDNF), c-ret proto-oncogene and GDNF receptor- $\alpha$ indicates multiple 
mechanisms of trophic actions in the adult rat CNS. J Neurosci 17:3554-3567.

Uesaka T, Jain S, Yonemura S, Uchiyama Y, Milbrandt J, Enomoto H (2007) Conditional ablation of GFRalphal in postmigratory enteric neurons triggers unconventional neuronal death in the colon and causes a Hirschsprung's disease phenotype. Development 134:2171-2181.

Wang CY, Yang F, He X, Chow A, Du J, Russell JT, Lu B (2001) $\mathrm{Ca}^{2+}$ binding protein frequenin mediates GDNF-induced potentiation of $\mathrm{Ca}^{2+}$ channels and transmitter release. Neuron 32:99-112.

Wang LJ, Lu YY, Muramatsu S, Ikeguchi K, Fujimoto K, Okada T, Mizukami H, Matsushita T, Hanazono Y, Kume A, Nagatsu T, Ozawa K, Nakano I (2002) Neuroprotective effects of glial cell line-derived neurotrophic factor mediated by an adeno-associated virus vector in a transgenic animal model of amyotrophic lateral sclerosis. J Neurosci 22:6920-6928.

Whitehead J, Keller-Peck CR, Kucera J, Tourtellotte WG (2005) Glial cell- line derived neurotrophic factor-dependent fusimotor neuron survival during development. Mech Dev 122:27-41.

Woolley A, Sheard P, Dodds K, Duxson M (1999) Alpha motoneurons are present in normal numbers but with reduced soma size in neurotrophin-3 knockout mice. Neurosci Lett 272:107-110.

Yeong SO, Subramaniam K, Vrbová G (1998) Organization of common peroneal nerve motoneurones in the rat and monkey: a comparative study. NeuroReport 9:1085-1088.

Zhang J, Huang EJ (2006) Dynamic expression of neurotrophic factor receptors in postnatal spinal motoneurons and in mouse model of ALS. J Neurobiol 66:882-895.

Zhao Z, Alam S, Oppenheim RW, Prevette DM, Evenson A, Parsadanian A (2004) Overexpression of glial cell line-derived neurotrophic factor in the CNS rescues motoneurons from programmed cell death and promotes their long-term survival following axotomy. Exp Neurol 190:356372. 